\title{
Revision and phylogenetic analysis of the subfamily Platerodinae (Coleoptera: Lycidae)
}

\author{
MILADA BOCÁKOVÁ \\ Regional Museum Olomouc, nám. Republiky 5, CZ-771 73 Olomouc, Czech Republic; e-mail: mbocakova@vmo.cz
}

Key words. Lycidae, Platerodinae, taxonomy, cladistics, new synonymy, redescriptions, new species, key

\begin{abstract}
Genus-group taxa of Platerodinae are revised and valid taxa are redescribed. The validity of Plateros Bourgeois, 1879 is reinstated. Libnetomimus Kleine, 1927 is made a junior synonym of Libnetis Waterhouse, 1878. Calleros Gorham, 1881, Calloplateros Pic, 1923, Costatoplateros Pic, 1949, Ditoneces Waterhouse, 1879, Libnetomorphus Pic, 1921, Microplateros Pic, 1921, Planeteros Gorham, 1883, Tolianus Pic, 1921, Melampyrus Waterhouse, 1879, and the subgenus Cautirodes Pic, 1921 are considered to be junior synonyms of Plateros Bourgeois, 1879. The subgenus Pseudeuplectus Pic, 1922 is synonymized to Cavoplateros Pic, 1913, and Pseudoplateros Green, 1951 is made a junior synonym of Falsocalleros Pic, 1933. Macrolibnetis Pic, 1938 formerly classified with Platerodini is synonymized to Platerodrilus Pic, 1921. Samoaneros Blair, 1928 is considered to be a junior objective synonym of Melaneros Fairmaire, 1877, which is excluded from Platerodinae and is kept incertae sedis in Lycidae. Fernandum Pic, 1924 and Subdihammatus Kleine, 1926 are transferred to the subfamily Leptolycinae. Teroplas oculatus sp. n. and Microlycus mexicanus sp. n. are described. Neotype of Plateros brasiliensis (Lucas, 1857) and lectotype of Microlycus minutus Pic, 1922 are designated. In order to understand relationships within the subfamily, included genus-group taxa were cladistically analysed.
\end{abstract}

\section{INTRODUCTION}

With about 900 recognized species, Platerodinae is the second largest subfamily of Lycidae after Metriorrhynchinae. Before this revision Platerodinae comprised 29 valid genus-group names (Bocák \& Bocáková, 1990a, 1992; Bocáková, 1997a; Miller, 1997). Most of them, especially those of M. Pic, have never been mentioned since they were proposed. After examination of extensive material, predominantly from south east Asia, it has become clear that many of these taxa are typologically defined groups of species of various relationships.

Most of the confusion in taxonomy of Lycidae was induced by taxa of a famous French author, Maurice Pic, a taxonomist of Coleoptera, Heteroptera, Diptera, Hymenoptera, and some other groups. He mostly published in Mélanges Exotico-Entomologiques and L'Echange where he was usually the single contributor. It is generally known that his descriptions were extremely brief. The problem of M. Pic's taxa is that they are not adequately defined and are compared often with distant taxa. Within Lycidae M. Pic proposed 44 genus-group taxa (Kleine, 1933), 29 of them are monotypic. These 44 taxa together contain only 139 species.

M. Pic's collection is predominantly composed of primary types, and in fact, does not contain other identified material or large paratype series. The reason is not extraordinary diversity, but absolute chaos. M. Pic described a single species of Pyrochroidae 17 times (D. $\mathrm{K}$. Young, pers. comm.), and described one series of a lycid species collected by J. B. Corporaal in a single location in Sumatra as 3 distinct species.

Confusion in genus-group taxa is similar to that at the alpha taxonomic level. Only by using prefixes Falso-, Flabello-, Gracilo-, Macro-, Micro-, Pseudo-, and compa- ring genera with representatives of other subfamilies (or sometimes even families) M. Pic proposed 30 mostly monotypic genera in Lycidae (other Pic's monotypic genera bear different names). None of these names was later cited, and most of them are indistinguishable from previously described genera. It is possible to say that around $50 \%$ of his genus-group taxa represent nothing more than another species. His genus Flabelloporrostoma based on a supernumerary third antenna, glued on a label under the holotype and which does not belong to the specimen, is a peculiar case.

Now, the question is how to solve this situation with many valid genus-group names for few real taxa. $R$. Kleine, another specialist in Lycidae, ignored all Pic's work, but this resulted in further synonyms. Other authors simply did not use Pic's taxa. However, these approaches cannot persist infinitely.

The cleanest solution would be to perform a phylogenetic analysis of the whole group at alpha-taxonomic level, and to synonymize taxa as a result of this analysis. Unfortunately, we have to work with very restricted data. Some old genera are based on a single female appearing no different from related species of other genera. It often happens that males, which have characters not expressed in females, are almost consistently classified in different genera than females. Moreover, we are often not able to associate males and females of relevant species, and even in the future it could be complicated. The possible ways to associate the sexes are either to capture a couple of specimens in copula, or to use DNA techniques to provide an unequivocal identification. Both the possibilities require collection of additional material. The difficulties are: (1) Capturing of mating specimens is a rare occasion. (2) Most of species on which the taxa are based were collected in lowlands of tropical regions that are now heavily 
deforested and, therefore, finding additional specimens is also a rare occasion. For example, when collecting in the Philippines I found only about 5\% overlap at species level when compared with Baker's material from 1920's. When studying the very extensive material of the Smithsonian Institution expeditions to Sri Lanka from 1970-1977, Bocák \& Bocáková (1990b) found only five described species, but 19 new species. (3) The use of molecular methods is dependent on the quality and quantity of DNA that can be extracted. These depend on preservation methods. A particular problem with pinned specimens from tropical collections is fungal growth (Townson et al., 1999). Also specimens killed with ethyl acetate and subsequently air-dried (which is the most common method to kill beetles) produced low yields of fragmented DNA (Dillon et al., 1996), and therefore the use of these techniques on M. Pic's type material will always be limited.

Regardless of these facts, I coded available characters of type species of genus-group taxa to solve relationships of the platerodine genera. The consequences of coding unknown character states of a sex (depending on which sex was available) are elucidated in the phylogenetic analysis section.

The subfamily Platerodinae was established by Kleine (1928) in his paper on Indian Lycidae. Later on, Kleine (1933) downgraded this subfamily to tribal status. The Platerodini of Green (1951) united Platerodini and Dictyopterini and his subtribe Platerodi included also some genera formerly placed in Dictyopterini (Lopheros LeConte). Nakane (1969) followed Green (1951) and left genera Lopheros and Eropterus Green within Platerodini, which was accepted by Bocák \& Bocáková (1990a). Recently Miller (1997) removed Eropterus and Lopheros from Platerodini to Erotini, falsified monophyly of Erotinae and raised Platerodini to subfamilial status again on the basis of larval characters. Unfortunately, the only genera of Platerodinae he examined (besides removed Lopheros and Eropterus) were representatives of the Plateros - Calleros - Ditoneces lineage that are here understood as a single genus Plateros. The other Platerodinae genera were beyond the scope of his paper and therefore, he kept them intact in the subfamily.

Despite several workers reporting immature stages of lycid beetles, our knowledge remains poor and cannot be generally used to infer the phylogeny of Lycidae. The main objective of this paper is to use evidence of adult morphology to conduct a phylogenetic analysis of genusgroup taxa placed within Platerodinae, in order to understand relationships within it, and to propose a natural tribal classification. Additionally, the resulting taxonomic and nomenclatural problems are addressed.

\section{MATERIAL AND METHODS}

About 4000 specimens of Platerodinae and other subfamilies were examined. Type specimens of type species of all genusgroup taxa were examined, except those of Microlyropaeus notaticollis Pic and Planeteros ochropterus Gorham (long-term loans), and except types of Sculptocalleros discithorax Pic, Plateros (Mimolycinella) basicornis Pic, and Libnetisia atri- cornis Pic which were not found in the Natural History Museum in Paris and seem to be lost.

Specimens were examined and illustrated using a Zeiss Technival stereoscopic microscope, with the magnification up to $125 \mathrm{x}$, and illustrated using either the drawing tube or the ocular microgrid.

All measurements are in millimetres. Somatic morphology measurements were taken using an ocular micrometer. Eye diameter and interocular distances are taken from the span of eyes. When the eye outline was not circular the diameter was measured at the widest point, the interocular distances at the narrowest point. The body width was measured at humeri in dorsal view. Male and female genitalia were dissected after having been boiled in $10 \% \mathrm{KOH}$ solution, membranous parts of female genitalia were then stained in chlorazol black and put into microvials containing glycerine and pinned below the respective specimens.

The numerical cladistic analysis was accomplished using Hennig86 computer program, version 1.5 (Farris, 1988), and applying the implicit enumeration option (Lipscomb, 1994). The tree length and consistency (Kluge \& Farris, 1969) and retention indices were calculated. Autapomorphies and the synapomorphy of Platerodinae (character 6) were excluded to avoid increasing the indices. Then a strict consensus tree was constructed using the "nelsen" command of Hennig86. To show the character optimization, Clados version 1.9 (Nixon, 1995) was employed using default settings for all parameters, including homoplasy (hom 0 ) that is to indicate as homoplasious only those changes that designate an independent origin of a state. Tree Gardener version 2.2 (Ramos, 1997) was used for editing the data matrix and quick processing. Support for individual clades was assessed using one of the computer programs from the package of Random Cladistics 4.0.3, Heyjoe version 3.0 (Siddall, 1996), a program for bootstrapping and jacknifing.

\section{DEPOSITORIES}

BMNH - The Natural History Museum, London (J. Beard) MNHN - Muséum d'Histoire naturelle, Paris (J. Ménier)

ZMPA - Zoological Institute, Warszawa (T. Huflejt)

MCSN - Museo Civico Di Storia Naturale, Genova, Italy (R. Poggi)

CASC - California Academy of Sciences, San Francisco, U.S.A. (R. Brett)

NMPC - The National Museum, Praha (S. Bílý)

ZMHB - Zoologisches Museum der Humboldt-Universität, LLL Berlin (F. Hieke)

LMBC - author's collection

\section{PHYLOGENETICS}

\section{Taxa}

Before this revision commenced, Platerodinae included 29 genus-group taxa. Seven of these taxa are excluded from the present analysis as terminal units for the following reasons. Two taxa (Fernandum, Subdihammatus) are transferred to subfamily Leptolycinae based on the presence of characters defined by Bocák \& Bocáková (1990a). Another two taxa (Melaneros, Macrolibnetis) are excluded from Platerodinae, being left incertae sedis in Lycidae, and three taxa (Sculptocalleros, Mimolycinella, Microlyropaeus) could not be examined (see above). The genus Microlyropaeus was only defined on the basis of published information (Kasantsev, 1997a), and consequently many of its characters could not be 
assessed. Because the inclusion of a taxon with many character states coded as "?" resulted in unresolved polytomy, Microlyropaeus was also excluded from the analysis, even though it is supposed to belong to Libnetini.

Therefore, together with Plateros represented 5 times by different species and with 3 outgroup taxa, the preliminary cladistic analysis involved 30 terminal taxa (Table 1).

A modified data matrix consisting of 13 terminal taxa and including 3 outgroup taxa was then assembled and analysed. The following genus-group taxa were deleted: Pseudoplateros, Calleros, Calloplateros, Costatoplateros, Ditoneces, Cautirodes, Libnetomorphus, Microplateros, Planeteros, Tolianus, Melampyrus, Libnetomimus. Plateros lanceolatus, P. jizushanensis, P. kubani, P. guineensis, $P$. cordatus were also excluded from the matrix, and therefore the genus Plateros was represented by a single taxon with the coding representing all known species. The reasons for deleting these taxa were as follows: (a) Pseudoplateros and Libnetomimus are bound (Fig. 1a) to Falsocalleros and Libnetis respectively (see

TABLE 1. Data Matrix

\begin{tabular}{|c|c|}
\hline character & 000000000011111111112222222222333333333344444 \\
\hline number & 012345678901234567890123456789012345678901234 \\
\hline Dictyoptera & 000000000000000000000000000000000000100000000 \\
\hline Taphes & 000000000100000000110000000000000000000000000 \\
\hline Lygistopterus & $1-01-00001000000000000000000000000001-0000000$ \\
\hline Lyponia & $010000100011000100110000000000001000110-00000$ \\
\hline Microlycus & $0010101011 ? ? ? ? 001001000000 ? ? ? ? ? ? ? ? 1010 ? ? 0 ? ? ? ?$ \\
\hline Calolycus & 001010101111000100110000000000100000100000000 \\
\hline Teroplas & $010010111100000110120001000000000000110-00000$ \\
\hline Pseudoplateros & $00001011110110 ? ? ? ? ? ? 00001000000000 ? ? 100000000$ \\
\hline Falsocalleros & 0000101111????011012000010????????0010?00???? \\
\hline Plateros & $010010111111110110120000001000000000-10---00$ \\
\hline Plateros lanceolatus & $01001011111111 ? ? ? ? ? ? 00000010000000 ? ? 110001100$ \\
\hline Plateros jizushanensis & $01001011111111 ? ? ? ? ? ? 00000010000000 ? ? 110000100$ \\
\hline Plateros kubani & $01001011111111 ? ? ? ? ? ? 00000010000000 ? ? 110100100$ \\
\hline Plateros guineensis & $01001011111111 ? ? ? ? ? ? 00000010000000 ? ? 110000010$ \\
\hline Plateros cordatus & $01001011111111 ? ? ? ? ? ? 00000010000000 ? ? 110000001$ \\
\hline Calleros & 010010111111110110120000001000000000010000000 \\
\hline Calloplateros & 010010111111110110120000001000000000110000000 \\
\hline Costatoplateros & 010010111111110110120000001000000000100101000 \\
\hline Ditoneces & 010010111111110110120000001000000000110101000 \\
\hline Cantirodes & $01001011111111 ? ? ? ? ? ? 00000010000000 ? ? 210100000$ \\
\hline Libnetomorphus & $0100101111111101101200000010000000 ? ? 110000000$ \\
\hline Microplateros & $01001011111111 ? ? ? ? ? ? 0000001000000000110000000$ \\
\hline Planeteros & 010010111111110110120000001000000000110010000 \\
\hline Tolianus & $0100101111 ? ? ? ? 011012000000$ ????????0011??0???? \\
\hline Melampyrus & $0100101111 ? ? ? ? 011012000000$ ? ???????0010??0???? \\
\hline Cavoplateros & $01001011111111 ? ? ? ? ? ? 00000100000100 ? ? 110000000$ \\
\hline Dihammatus & 010010111101001101110000000000000001010000000 \\
\hline Libnetis & $1-01-11121010011111111100001010001002-0000000$ \\
\hline Libnetomimus & 1-01-111210100??????11100001010001??2-1000000 \\
\hline Libnetisia & 1-01-111110100??????00000000100000??1-0000000 \\
\hline
\end{tabular}

comments on Falsocalleros and Libnetis). (b) Most of these taxa, when they were proposed, were known from a cies were examined, the characters these taxa were based on were often found to be transitional states. The extent of expression used for erecting of genus forms was only one extreme in the continuous variability of the character (see comments on Plateros - comments on synonymization of individual genera).

\section{Characters, polarity and coding}

The following section describes the main features of characters and character states used in the cladistic analysis. The explicit character and character state definitions are also given.

For this cladistic analysis representatives of two Erotinae tribes (genera Dictyoptera and Taphes Waterhouse) are used as outgroups, and are based on Dictyoptera aurora Herbst, 1784 and Taphes brevicollis Waterhouse, 1879 respectively. Because some convergence was suspected, the genus Lygistopterus Mulsant single or few specimens. When more specimens and spelycid morphology and how they are allocated into the 


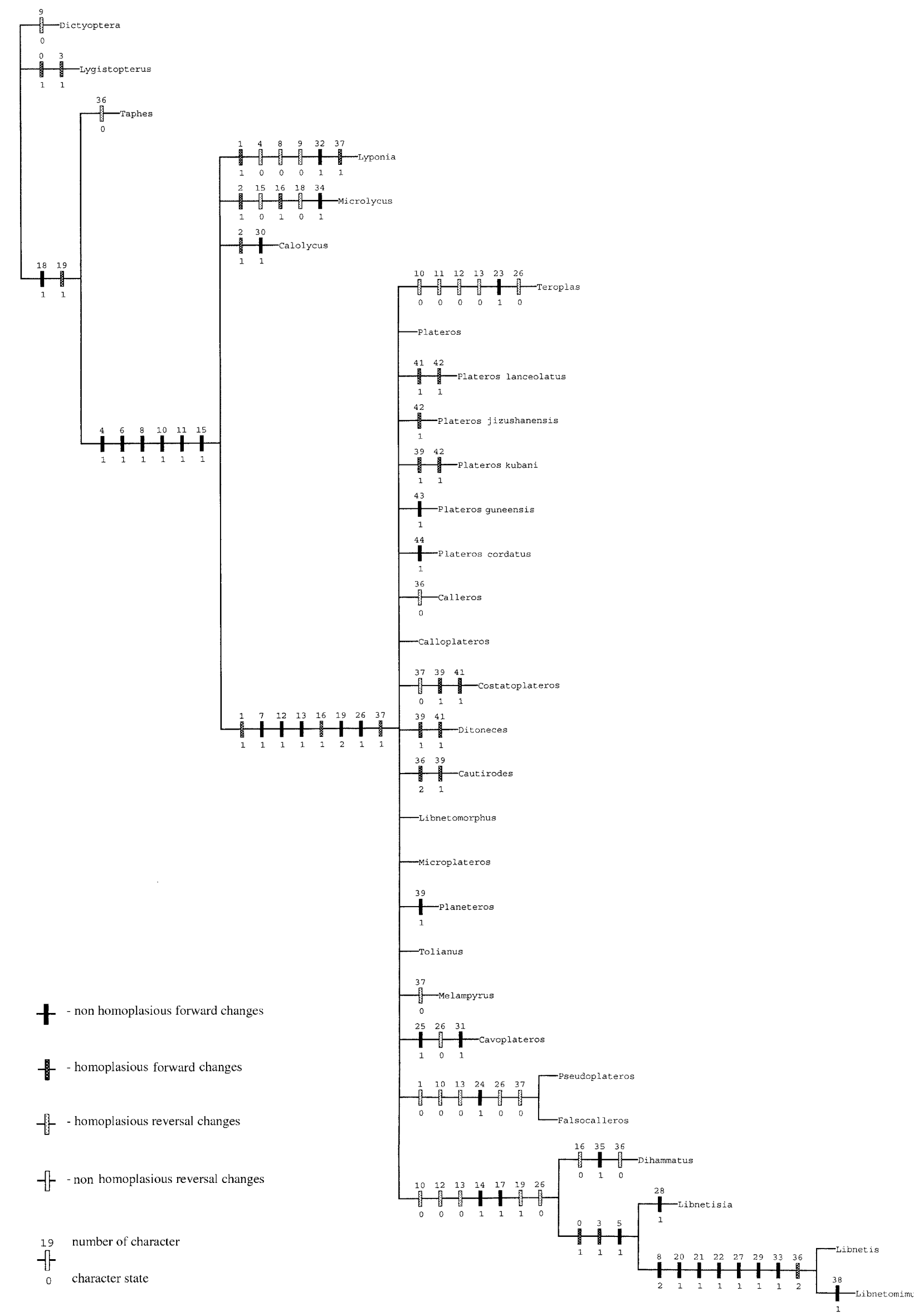

Fig. 1a. The strict consensus tree of 3058 trees output by Hennig 86 procedures "mh*; bb*; nelsen;". 
(Calochrominae) based on Lygistopterus sanguineus Linnaeus, 1758 was included as another outgroup.

The data matrix is composed of 45 adult characters. The male and female genital morphology provides the largest suite of characters for the study of Platerodinae. Polarity of characters was determined by outgroup comparison method (Watrous \& Wheeler, 1981). Because the sister group relationships cannot be identified with certainty, three real outgroup taxa (Dictyoptera, Taphes, Lygistopterus) were coded and employed directly in a simultaneous, unconstrained analysis to avoid the need to assign a priori polarity to characters. A missing data code, "?", was used when the character state was unknown (usually when only one sex was examined). Missing character states of taxa that do not exhibit the character in question, were represented by a dash (-). Multistate characters were treated as unordered. A data matrix of 30 terminal taxa by 45 characters was constructed shown in Table 1.

In the modified data matrix composed of 13 terminal taxa (see above) characters $37-44$ had to be switched off. These characters were uniform for remaining taxa in the analysis (taxa coded by 0 ), or were present in both states in some taxa (coded by a dash "-"), i.e. all taxa were coded by 0 or -. Characters 2 and 37 encode in fact one multistate character and after exclusion of above given taxa their coding for remaining taxa was identical. Therefore character 37 had to be excluded from the matrix, otherwise character 2 was assigned a priori double weight.

\section{Characters and scoring of states}

Below are listed all the characters used for the cladistic analysis and the coding of states.

\section{Character 0 - Number of elytral costae}

0 , nine costae on each elytron; 1 , four costae on each elytron.

Character 1 - Primary and secondary costae

0 , strongly distinguished, primary costae considerably stouter; 1 - not distinguished or very weakly distinguished each other.

Character 2 - Primary costae 2 and 4

0 , as strong as costae 1 and $3 ; 1$, more elevated than costae 1 and 3 .

Character 3 - Reticulate cells on elytra

0 , present; 1 , absent.

Character 4 - Shape of reticulate cells

0 , more or less rectangular; 1 , rather oval, of irregular shape.

Character 5 - Median longitudinal carina on pronotum 0 , absent; 1 , present only in anterior half.

Character 6 - Transverse pronotal carinae forming areolae

0 , present; 1, absent.

Character 7 - Pronotum

0 , flat to concave medially; 1 , median longitudinal line channelled at base (of Platerodinae-like shape).

Character 8 - Mesosternum
0 , trianguloid medially; 1 , rather trapezoidal medially, almost as long as wide; 2, trapezoidal, strongly transverse.

Character 9 - Trochanters

0 , trianguloid; 1 , elongate.

Character 10 - Paramerae

0 , present; 1 , absent.

Character 11 - Paramerae

0 , long, almost as long as the phallus; 1 , strongly shortened to absent.

Character 12 - Base of phallus dorsally

0 , simple, without any projection; 1 , projected in a small almost pointed projection.

Character 13 - Phallobase: its attachments to phallus

0 , stick formed, in the same plain as the phallobase itself; 1 , trianguloid, deflected ventrally.

Character 14 - Female genitalia with paraprocts 0 , absent; 1 , present.

Character 15 - Ovipositor: coxites

0 , basally coalescent to each other; 1 , loose.

Character 16 - Valvifers

0 , stick shaped; 1 , widened basally (each valvifer basally as wide as the coxite in basal portion).

Character 17 - Inner basal margins of coxites

0 , usually approached to each other; 1 - basally emarginate and distant.

Character 18 - Length of valvifers

0 , valvifers long; 1 , short, at most as long as width of the ovipositor.

Character 19 - Spiculum gastrale

0 , long, usually twice longer than the terminal sternum; 1 , short, at most as long as terminal sternum; 2, absent.

Character 20 - Labrum

0 , transverse; 1 , longer than wide.

Character 21 - Lacinia

0 , present; 1 , absent.

Character 22 - Mandibles

0 , arcuate; 1 , strongly reduced, straight, almost trianguloid.

Character 23 - Antennae

0 , short; 1 , long (reaching apical $1 / 4$ of elytra).

Character 24 - Secondary costae

0 , fully evolved; 1 , strongly shortened, present only basally.

Character 25 - Hind femora

0 , simple; 1 , provided with a spine.

Character 26 - Basal quarter of phallus

0 , simple; 1 , with a bulb-shaped enlargement, then constricted before its base.

Character 27 - Proximal portion of male terminal sternum 0 , simple; 1 , forming a widened base to which projections of penultimate tergum are attached.

Character 28 - Male terminal sternum

0 , simple; 1, with two bow-shaped lateral emarginations.

Character 29 - Phallus

0 , tubular, with a small orifice apically; 1, dorsoventrally flat, entirely opened ventrally.

Character 30 - Male genitalia: base of phallus ventrally 


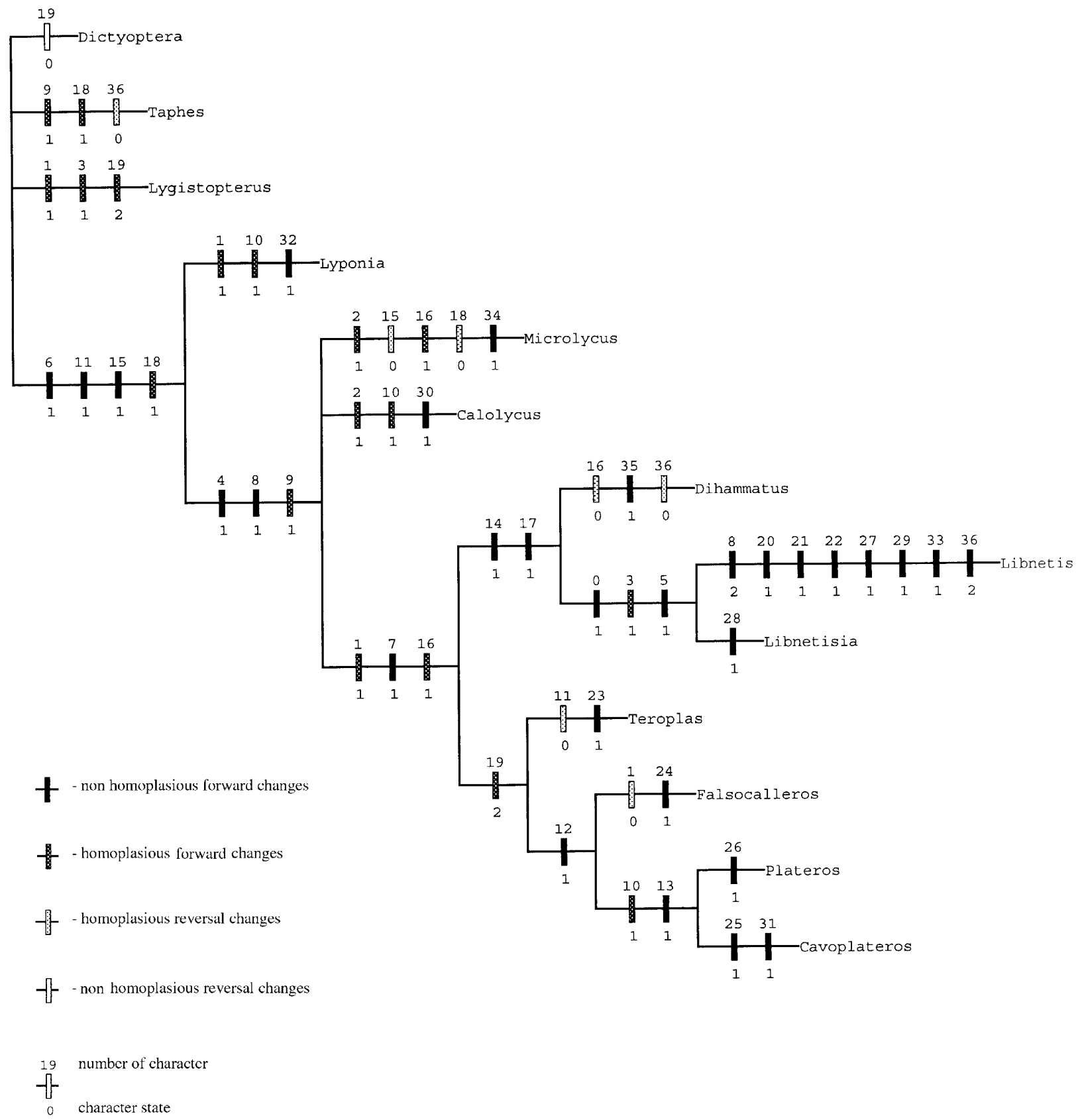

Fig. 1b. The strict consensus tree of the three trees output by Hennig86 procedures "ie*; nelsen;", after exclusion of the synonymized taxa from the matrix.

0 , simple; 1 , emarginate.

Character 31 - Male genitalia: base of phallus ventrally

0 , simple; 1 , with a ventrobasal projection.

Character 32 - Phallobase

0 , elongate, oblong to oval; 1 , hemispherical.

Character 33 - Phallobase

0 , elongate, oblong to oval; 1 , transverse.

Character 34 - Valvifers

0 , separate; 1 , basally coalescent to each other.

Character 35 - Female genital ducts: proximal vaginal glands

0 , widely attached to vagina at its proximal portion; 1 , attached to vagina by filaments.
Character 36 - Length of antennomere 3

0 - short, as long as 2;1 - at least 1.3 times longer than 2 , but shorter than $4 ; 2$ - as long as 4 .

Character 37 - Primary and secondary elytral costae 0 - at least very weakly distinguished; 1 - not distin guished at all.

Character 38 - Male antennae

0 - simply filiform or flabellate; 1 - only antennomere 7 with a lamella.

Character 39 - Male antennae

0 - filiform; 1 - acutely serrate to flabellate

Character 40 - Colour of terminal antennomere 0 -black; 1 -yellow. 

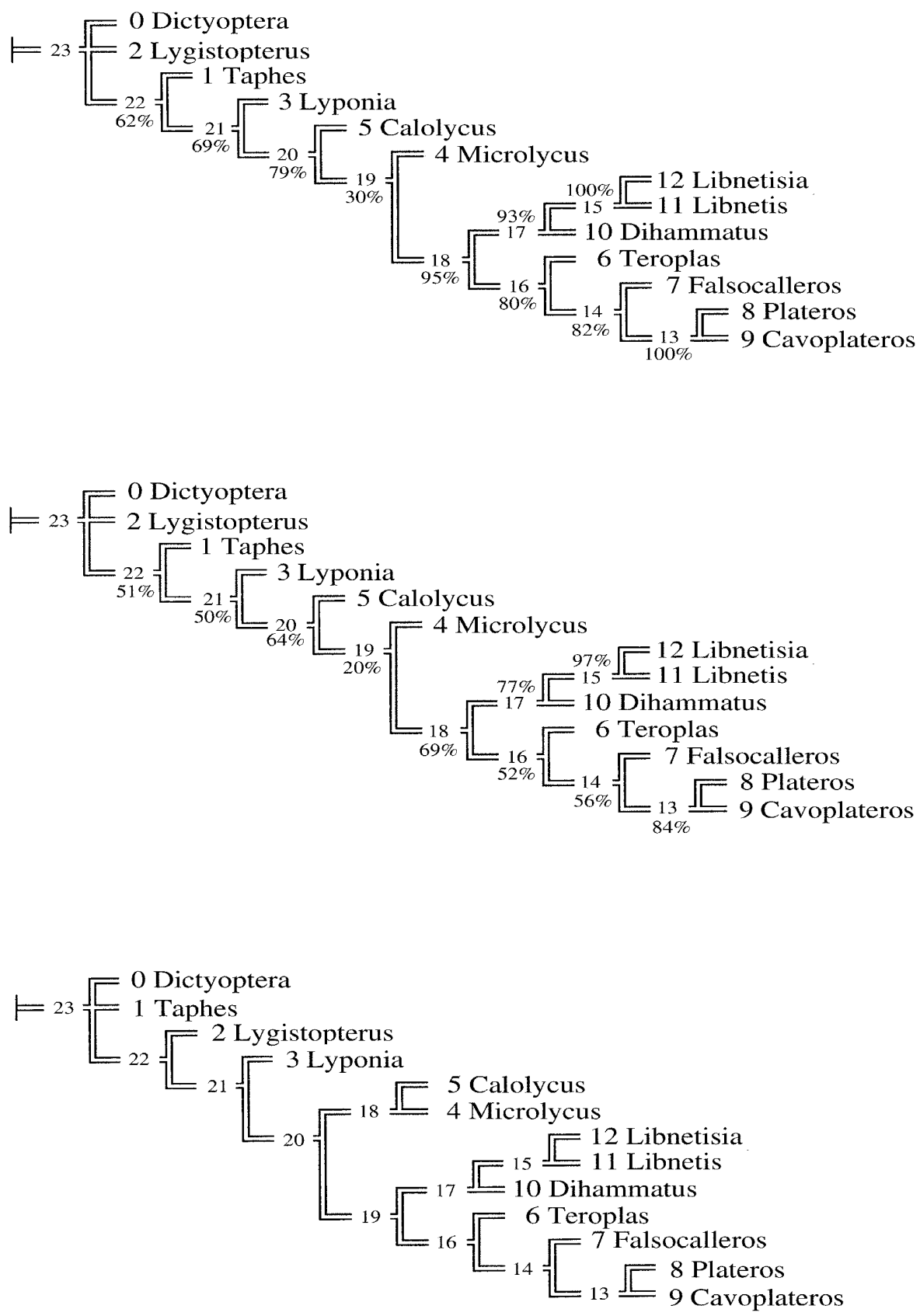

Figs 2-4: 2 - The first of three minimum-length trees accomplished by Hennig86 "ie" command with bootstrap percentiles for all monophyletic groups; 3 - "Jackboot" values for all monophyletic groups of the first of minimum-length trees accomplished by Hennig86 "ie" command; 4 - The third of three minimum-length trees accomplished by Hennig86 "ie" command. The tree of the same topology was obtained by successive weighting.

Character 41 - Phallus

0 - simple medially; 1 - strongly hooked dorsally in median portion.

Character 42 - Longitudinal hole in distal half of aedeagus

0 - absent; 1 - present.

Character 43 - Aedeagus

0 - without a lateral dent; 1 - with a lateral dent.

Character 44 - Orificial sclerite of aedeagus

0 - absent; 1 - present.

\section{Phylogenetic analysis}

The analysis of data matrix given in tab. 1 using commands "mh*; bb*;" yielded over 3058 most parsimonious cladograms (overflow) of 55 steps length, a CI of 63 and RI of 81 . When the strict consensus tree was generated using the nelsen command, the resultant cladogram (Fig. 1a) was of 75 steps length, a CI of 46 and RI of 63. The consensus tree is much longer than the most parsimonious trees because many branches collapsed due to ambiguous support. The matrix encompasses many unknown character states coded by "?" (as only one sex of many taxa is known), and therefore the consensus tree contains a large unresolved polytomy of terminal taxa belonging to tribes 

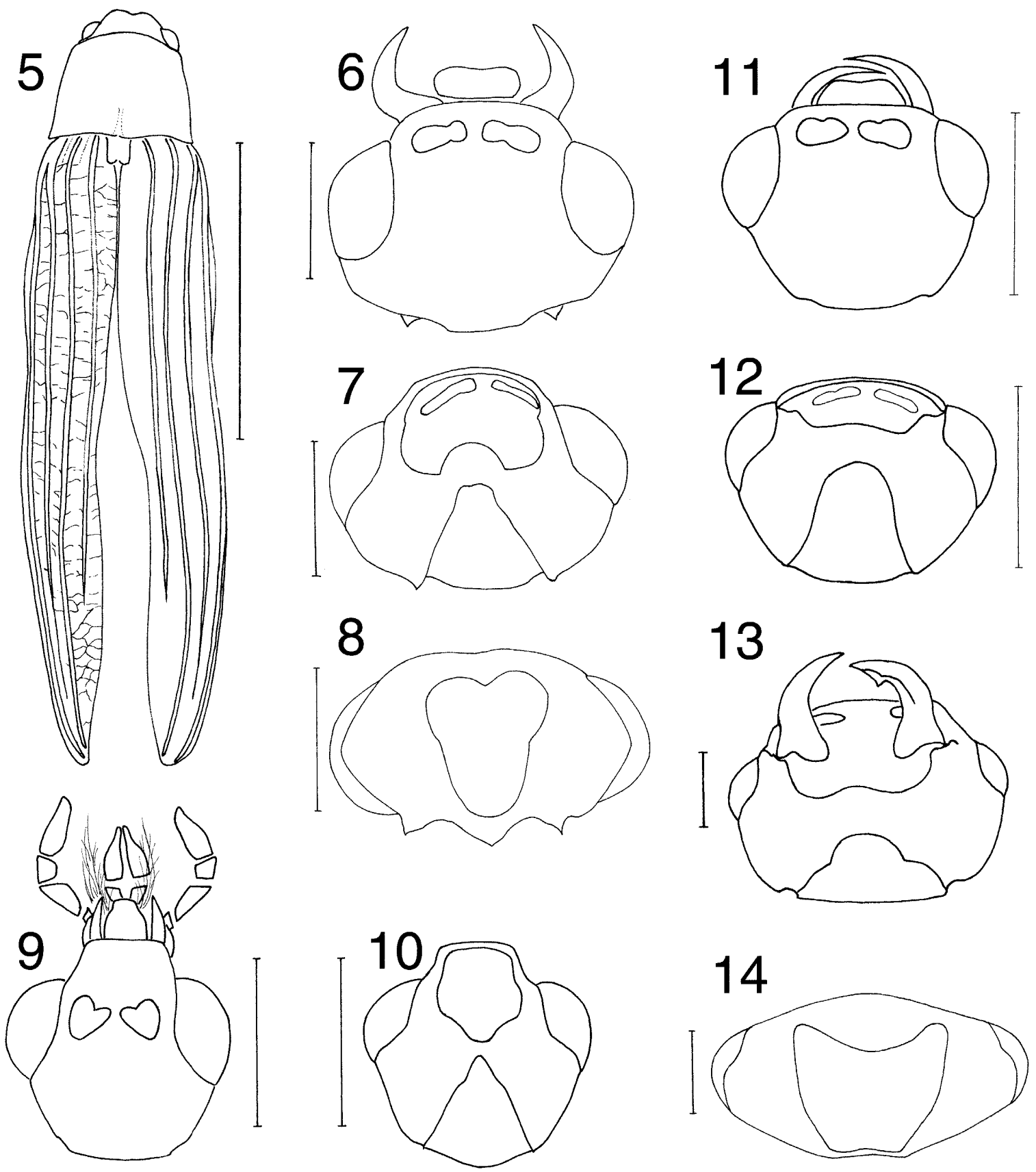

Figs 5-14: 5 - Falsocalleros particularis, dorsal view. 6-14: Head. 6-8: Plateros planatus; 9-10: Libnetis piceovittatus; 11-12: Dihammatus sp. (Mindanao); 13-14: Lyponia himalejica. Scale $=0.5 \mathrm{~mm}$.

Libnetini and Platerodini. Only Libnetomimus and Pseudoplateros can be synonymized as a result of the analysis of the whole data matrix (Fig. 1a).

Afterwards, all the synonymized taxa were excluded from the matrix as well as relevant characters (ch 37-44), and the genus Plateros was represented only by one taxon, similarly as remaining taxa in the matrix. The reason for deleting these taxa is explained in previous section.

The reduced matrix included taxa Dictyoptera, Taphes, Lygistopterus, Lyponia, Microlycus, Calolycus Teroplas, Falsocalleros, Plateros, Cavoplateros, Dihammatus, Libnetis, Libnetisia, and characters $0-36$ of the matrix given in tab. 1. The analysis of reduced data matrix using implicit enumeration option yielded 3 most parsimonious cladograms of 37 steps length, a CI of 62 and RI of 68 (trees 1 and 3 - Figs 3, 4; 2nd tree was of the same topology as in fig. 4, except the positions of outgroup taxa Lygistopterus and Taphes which are reversed). The strict consensus tree using the nelsen command yielded in two steps longer cladogram of CI-58, RI-64 (Fig. 1b), where the position of genera Calolycus and Microlycus is unresolved. If the successive weighting was applied, the same procedure yielded in single cladogram of the same topology as in Fig. 4, where genera Calolycus and Microlycus form a monophyletic group. 


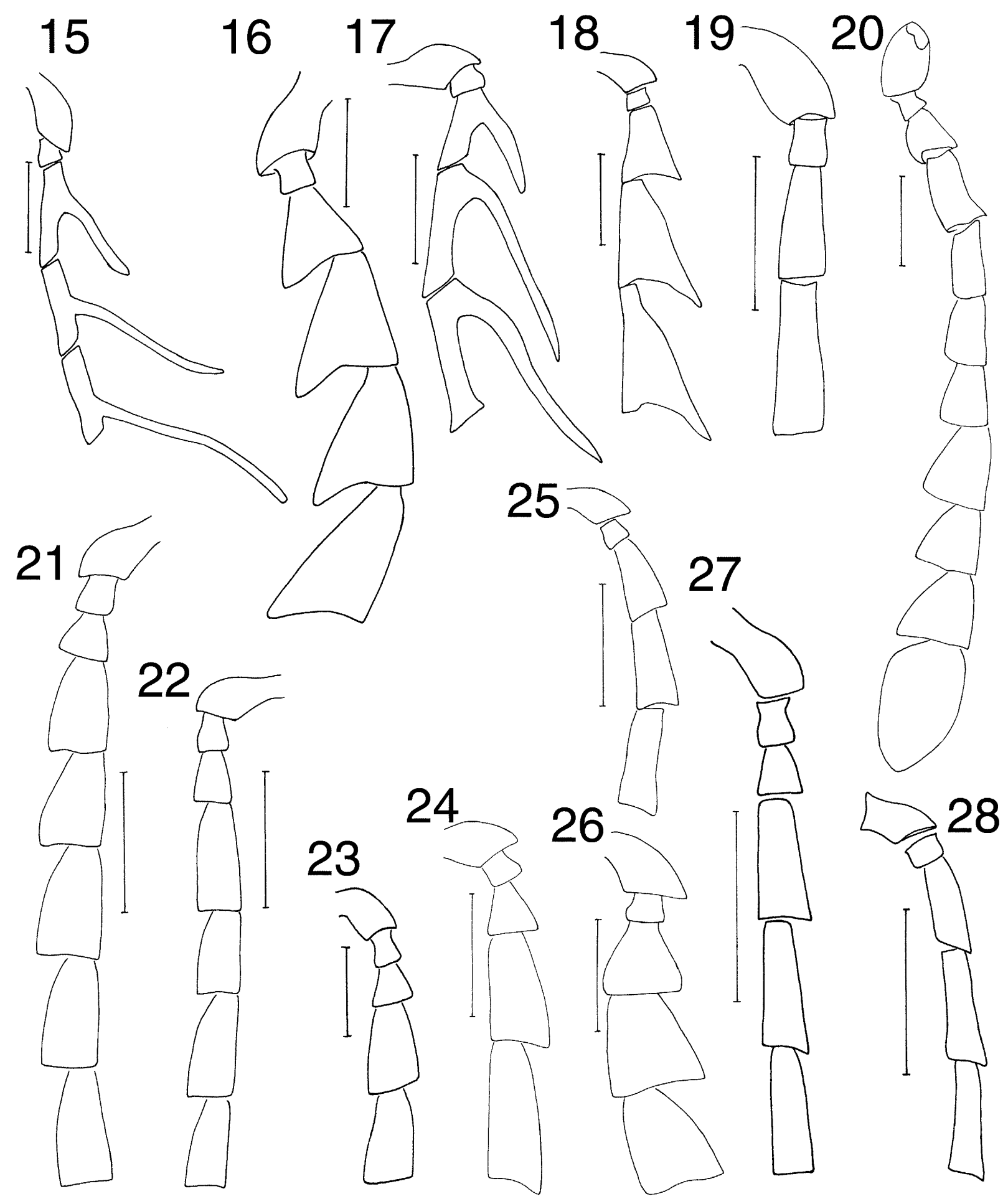

Figs 15-28: Male basal antennal segments. 15 - Plateros gorhami (Pic); 16 - Plateros brasiliensis (Lucas); 17 - Teroplas fusculus; 18 - Teroplas oculatus; 19 - Cavoplateros dentatus; 20 - Cavoplateros spinipes; 21 - Microlycus mexicanus sp. n.; 22 - Microlycus minutus; 23 - Plateros puniceus; 24 - Calolycus calanticatus; 25 - Plateros cephalotes (Pic); 26 - Falsocalleros particularis; 27 - Dihammatus sp.; 28 - Libnetis piceovittatus. Scale $=0.5 \mathrm{~mm}$.

Platerodinae are supported by 3 synapomorphies (ch 6 , $11,15)$ two of them (ch 11,15) have each a reversal. Nevertheless, the coding of character 15 for Microlycus is not certain because its coxites are only slightly coalescent. Thus, it would be possible to treat character
15 as multistate, coded by state 2 for Microlycus. Then also this character would have no reversal in Platerodinae.

The interrelationships of Platerodinae genera have remained out of interest of previous authors, and the initial placement of most genera (Kleine, 1928, 1933) has never been explicitly justified. Bocák and Bocáková 

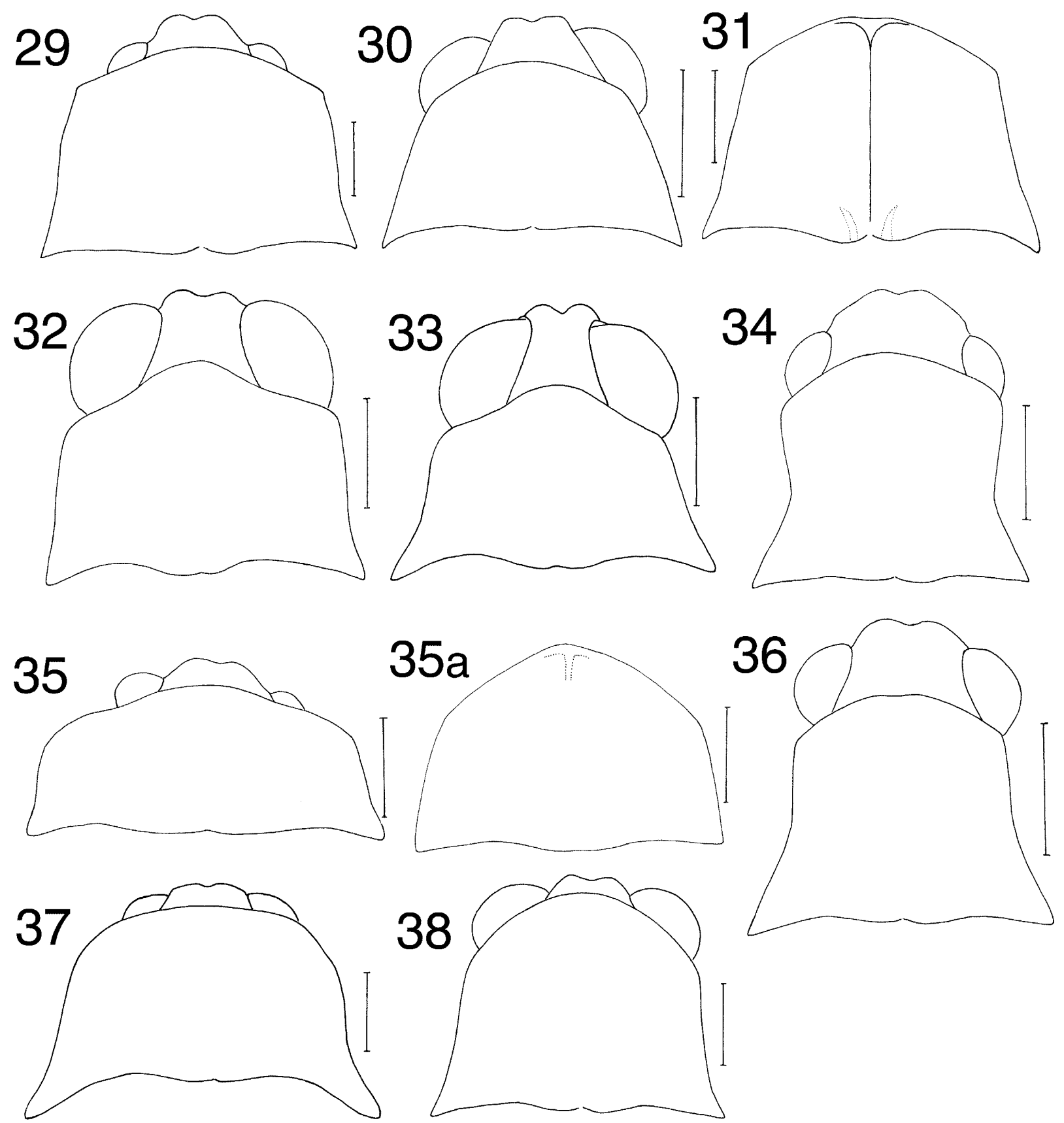

Figs 29-38: Head and pronotum. 29 - Plateros atroviolaceus; 30 - Plateros cephalotes; 31 - Plateros particularis (Pic); 32 -Teroplas fusculus; 33 - Teroplas oculatus sp. n.; 34 - Cavoplateros spinipes; 35 - Microlycus minutus; 35a - Microlycus mexicanus sp. n.; 36 - Cavoplateros dentatus; 37 - Calolycus calanticatus; 38 -Plateros brasiliensis (Lucas). Scale $=0.5 \mathrm{~mm}$.

(1990a) examined only the tribal classification, and they proposed the subfamily as a tribe Platerodini and established here three subtribes: Lyponiina, Libnetina and Platerodina. But examination of type specimens of all genus-group taxa was beyond the scope of that paper.

Bocák \& Bocáková (1990a) proposed sister-group relationships of the genus Lyponia and Platerodini in the restricted sense, and considered Libnetini to be a sister group of Lyponia - Platerodini lineage. According to the present phylogenetic hypothesis (Fig. 1b) Lyponia has a more basal placement and is the sister-group of Libnetini and Platerodini. There are several apomorphies supporting Lyponiini as a separate clade: shape of the phallo- base and phallus, prolonged basal part of coxites and an attachment of valvifers. The clade Platerodini - Libnetini - Microlycus - Calolycus is defined by 3 synapomorphies, especially the shape of mesosternum, different shape of reticulate cells, as well as by the prolonged trochanters, which seems to be a homoplasy shared with Taphes.

Microlycus and Calolycus have a basal placement in the strict consensus tree, placed after Lyponia but before Libnetini and Platerodini. The monophyly of the clade Microlycus and Calolycus is uncertain. They form two successive branches in the first most parsimonious tree. In the 2 nd and $3 \mathrm{rd}$ of the three most parsimonious trees (Fig. 4 ), as well as in the single tree obtained after successive 


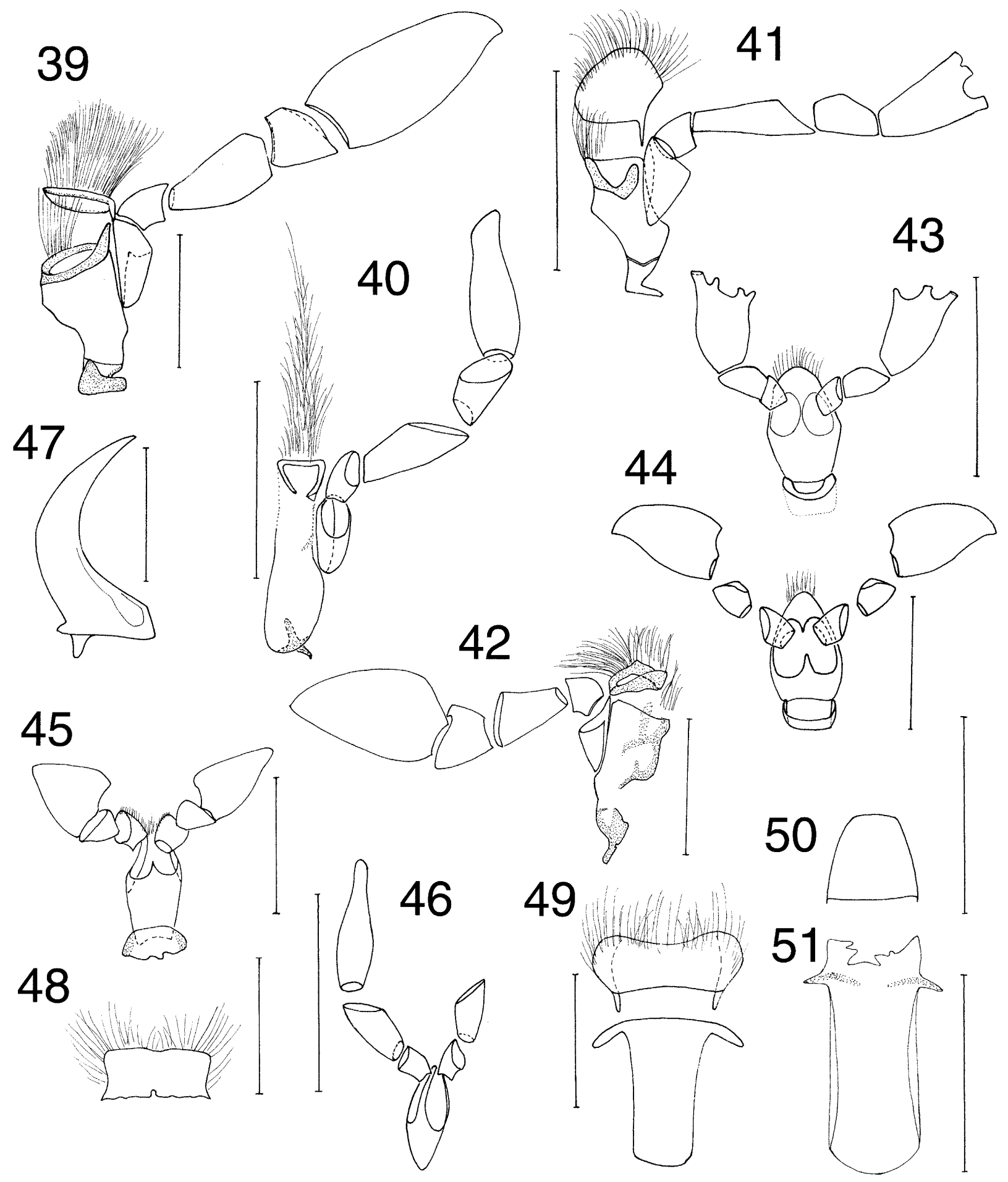

Figs 39-51. 39-42: Maxilla. 39 - Plateros planatus; 40 - Libnetis piceovittatus; 41 - Dihammatus sp.; 42 - Lyponia himalejica. 43-46: 43 - Dihammatus sp.; 44 - Plateros planatus; 45 - Lyponia himalejica; 46 - Libnetis piceovittatus. 47 - mandible of Plateros planatus; 48 - labrum of Lyponia himalejica; 49 - labrum and hypopharynx of Plateros planatus; 50-51: Libnetis piceovittatus. 50 - labrum; 51 - hypopharynx. Scales for figs 39-41, 43-44, 46, 47, 49-51-0.25 mm; scales for figs 42, 45, $48-0.5 \mathrm{~mm}$

weighting, these genera form a monophyletic group. Microlycus and Calolycus differ from other Platerodinae in having primary costae 2 and 4 elevated (ch2), and therefore their general appearance is rather different. Nevertheless, the clade Microlycus + Calolycus + Platerodini+Libnetini is well supported (see above). Although Microlycus and Calolycus resemble each other superfi- cially, they differ substantially in the morphology of female genitalia. Besides, another apomorphic feature that supports the monophyly of the clade is the absence of paramerae (ch 10), which is only a result of character optimization because male of Microlycus is not known. For these reasons, because of low bootstrap and jackboot values, and particularly because the clade has split in the 

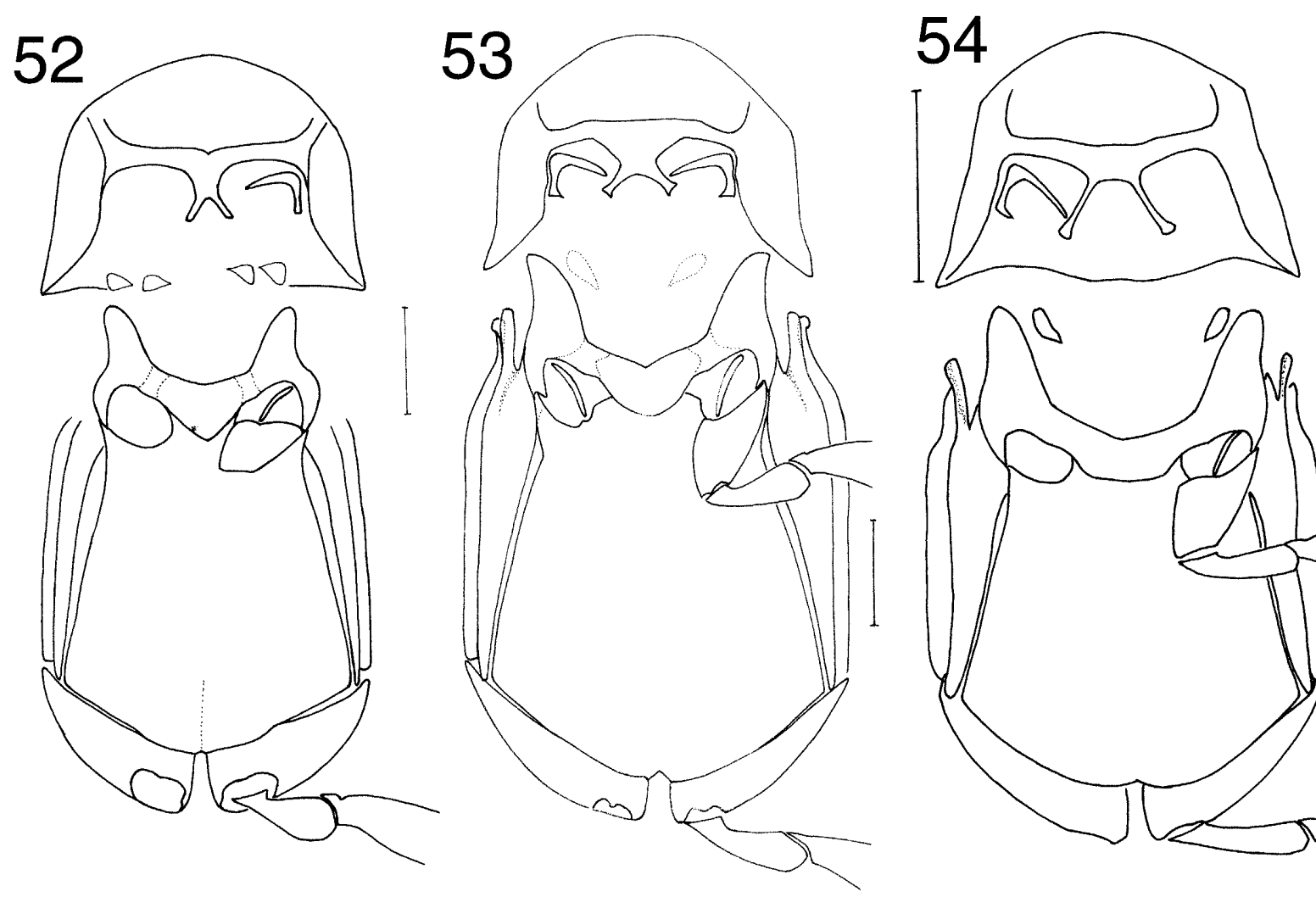

\section{5}

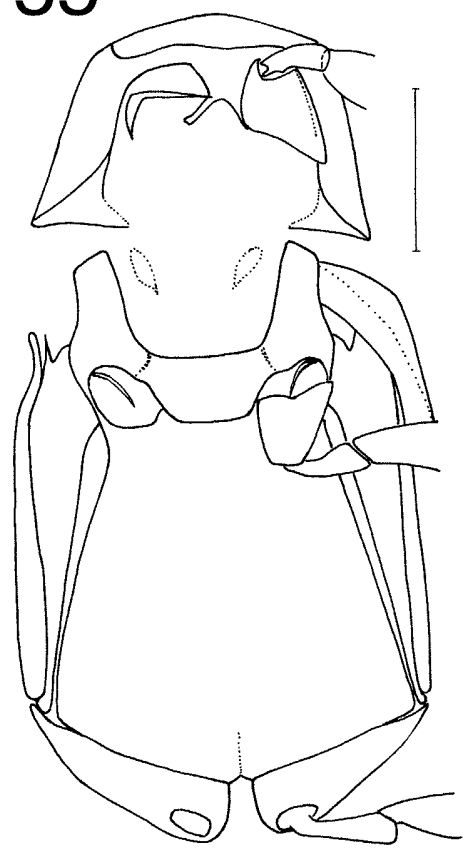

56

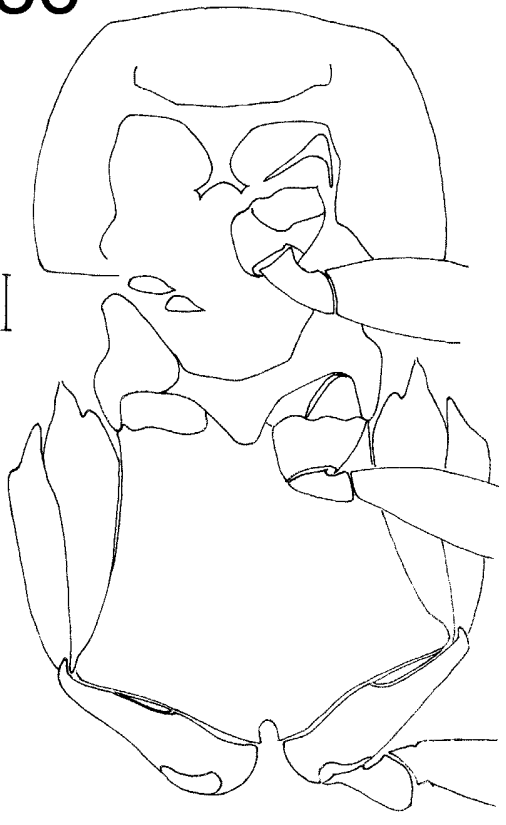

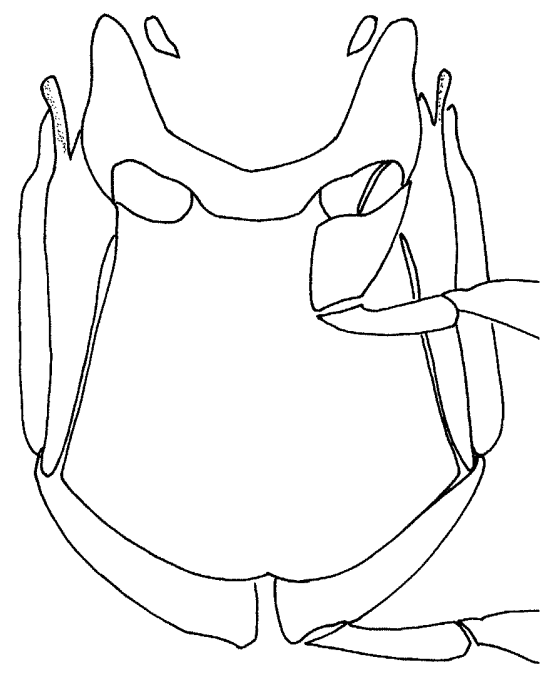

57

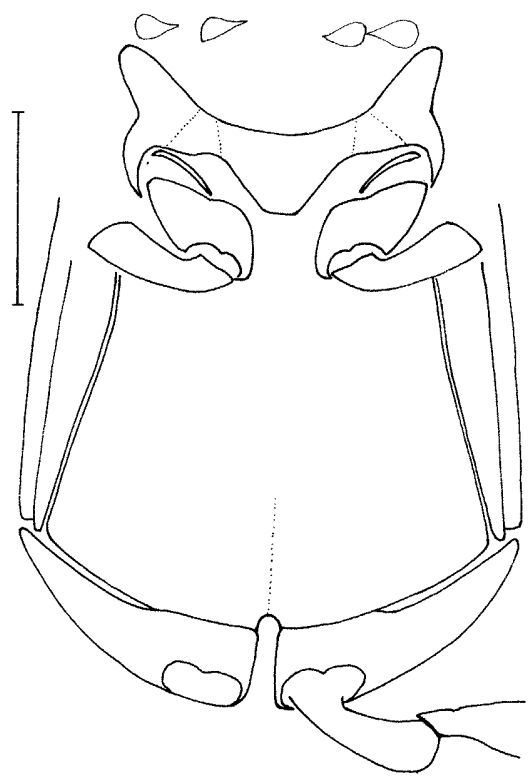

Figs 52-57: Thorax, ventral view. 52 - Plateros puniceus; 53 - Plateros planatus; 54 - Libnetis piceovittatus; 55 - Dihammatus sp.; 56 - Lyponia himalejica; 57 - Teroplas fusculus. Scale $=0.5 \mathrm{~mm}$.

strict consensus tree, Microlycus and Calolycus are kept incertae sedis within Platerodinae.

Dihammatus, formerly placed in the Platerodini lineage (Bocák \& Bocáková, 1990a) is considered the basal member of Libnetini. The evidence supporting the closer relationship of Dihammatus with Libnetini, instead of with restricted Platerodini, is based on female genitalia characters (presence of paraprocts - ch 14, inner basal margin of coxites emarginate and distant - ch 17). The close relationship between Dihammatus and other Libnetini, proposed here, is not so evident from the adult external morphology (presence of reticulate cells - ch 3, and secondary costae on elytra - ch 0 - absent in Libnetis and Libnetisia both being plesiomorphies). No data on 
larvae and pupae of these genera are available, but they may be valuable for better resolution of the phylogenetic relationships.

The monophyly of Platerodini is supported by one synapomorphy - absent spiculum gastrale (ch 19). This character has evolved several times within Lycidae, and may be a result of parallel evolution also in Platerodini. It is the only character supporting placement of the genus Teroplas at the base of Platerodini and therefore, the position of Teroplas, having long paramerae and many autapomorphies in the structure of phallus, within Platerodini is rather tentative.

The sister-group relationship of Falsocalleros and the Plateros - Cavoplateros lineage is clearly supported by a male genital character (stick-formed phallus provided with a dorsobasal pointed projection - ch 12). The close relationship of the speciose Plateros and the American Cavoplateros is well supported by entirely absent paramerae and the shape of the phallobase.

\section{Tests for reliability of the clades of the cladogram}

Various tests have been published for assessing confidence in the clades of a cladogram. In testing the reduced data matrix composed of 13 terminal taxa (when the synonymized taxa were excluded) I have used two randomization procedures - bootstrapping and jackknifing. Because these methods are affected by the inclusion of uninformative characters (Carpenter, 1996), these were excluded from the matrix (ch 6 and $20-35$ ). The new modified matrix was analysed using Heyjoe version 3.0 in M. Siddall's (1996) Random Cladistics package version 4.0.3. For bootstrapping the keyword "weight" was used to re-weight characters randomly, while the sum of weights must equal the original number of characters. For the jackknife M. Siddall's "jackboot” (Siddall, 1996) was applied using the "rcd" command (random character deletion, where deleted characters are not replaced by others). 1000 replicates were generated in both the analyses - the bootstrap and the jackknife, the most parsimonious cladogram for each replicate was then found, and the degree of conflict among them assessed by means of a majority rule consensus tree. The ten monophyletic groups present in the tree are given bootstrap (Fig. 2) and jackboot (Fig. 3) percentiles on the tree. The clade Microlycus - Calolycus present only in the second and the third most parsimonious trees (which only differed in the position of outgroup taxa Lygistopterus and Taphes) had low bootstrap values (bootstrap $-50 \%$, jackboot $-42 \%$ ).

\section{TAXONOMY}

\section{Subfamily Platerodinae Kleine, 1928}

Platerodinae Kleine, 1928: 2. (Type genus: Plateros Bourgeois, 1879).

Platerodi: Green, 1951:2

Platerodini: Nakane, 1969: 47.

Platerodinae: Miller, 1997:11.

Diagnosis. Small to medium-sized lycid beetles with inconspicuous antennal tubercles, antennae mostly filiform, in some genera pectinate in males and serrate in females. Pronotum transverse, mostly subpentagonal and widest at base, all margins narrowly reflexed, sides more broadly. Disc convex, weakly elevated dorsally, without carinae, median longitudinal line basally channelled, forming small median depression at basal margin, sometimes more or less carinate (except Microlycus and Calolycus). Scutellum oblong, at most impressed apically. Each elytron usually with 9 longitudinal costae, five intercostae absent in most of Libnetini. Male genitalia with paramerae absent or strongly shortened (only in the genus Teroplas paramerae long). Female genitalia with separate coxites (except the genus Microlycus).

Composition. Platerodinae as here understood contain Lyponiini (Lyponia), Libnetini (Dihammatus, Libnetis, Libnetisia, Microlyropaeus), Platerodini (Teroplas, Falsocalleros, Plateros, Cavoplateros), and 3 genera incertae sedis (Microlycus, Calolycus, Sculptocalleros) position of which has not been resolved. The classification reflects the hypothesis based on the strict consensus tree (Fig. 1b).

Distribution. Platerodinae are distributed in all zoogeographic regions, although they are missing in most of the Palaearctic (Europe, north-western Asia) and almost entirely in Australia where it has been recorded only in northern Queensland (Plateros handschini Kleine).

\section{KEY TO GENERA OF THE SUBFAMILY PLATERODINAE}

1 Each elytron with 4 primary costae, secondary costae and reticulate cells absent $\ldots \ldots \ldots \ldots \ldots \ldots \ldots \ldots$

- Each elytron with 9 costae, reticulate cells present .... 3

2 Mandibles arcuate, terminal palpomeres securiform, pronotum with weak median longitudinal carina in anterior half, mesosternum trapezoidal, aedeagus with paramerae shorter than half of phallus and laterally incorporated into it, ventrally separate (Fig. 127) . . . . . . . . . . Libnetisia Mandibles reduced, usually trianguloid, terminal palpomeres of both palpi tapering to apex, almost pointed apically, median longitudinal carina almost absent also in anterior half of pronotum, mesosternum strongly transverse, paramerae usually longer than half of phallus, ventrobasally fused (Figs 125a-b) . . . . . . . . . . . . . Libnetis

3 Antennomere 3 rounded, short, as long as $2 \ldots \ldots \ldots 4$ Antennomere 3 flattened, long, at least 1.3 times as long as

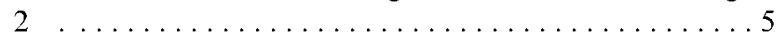

4 Phallus basally broad and dorsoventrally flattened in distal half, paramerae mutually separate, as $\log$ as half of phallus .......................... Microlyropaeus

Phallus reduced, paramerae dorsally entirely fused, ventroproximally close to coalescent (Figs 123, 124), valvifers stick-formed (Fig. 138) ............. Dihammatus

5 Paramerae present .................... 6

Paramerae absent . . . . . . . . . . . . . . 7

6 Paramerae almost as long as phallus (Figs 112-113)..... . ........................... Teroplas Paramerae short, as long as third of phallus (Figs 109, 110). Falsocalleros

7 Elytral primary costae 2 and 4 stronger than 1 and $3 \ldots .8$

- Elytral primary costae 2 and 4 as strong as 1 and $3 \ldots \ldots 9$

8 Ovipositor with coxites basally coalescent to each other, valvifers basally widened (Figs 128, 132) ......Microlycus Ovipositor with coxites mutually separate, valvifers stickformed (Fig. 130) . . . . . . . . . . . . . . . . Calolycus 
9 Elytra with transverse, rectangular reticulate cells, mesosternum trianguloid, phallobase annuliform, phallus often bearing a pair of side hooks distally (Bocák \& Bocáková, 1990a, fig. 139), ovipositor elongate, with small styli (Fig. 129), spiculum gastrale present, short . . . . . Lyponia Elytral reticulate cells oval or irregular, mesosternum rather trapezoidal, phallobase elongate, ovipositor short, styli approximately as long as half of the coxite, spiculum gastrale absent . . . . . . . . . . . . . . . . . . . . . . . . 10

10 Male hind femora provided with a spine (Figs 69, 70), base of phallus with ventral projection (Figs 101, 104) .

Cavoplateros

- Hind femora simple, ventroproximal projection of phallus absent, phallus bulb-shaped in basal portion (Figs 95-98) .

\section{Tribe Lyponiini Bocák \& Bocáková, 1990}

Lyponiinina Bocák \& Bocáková, 1990a: 652. (Type genus: Lyponia Waterhouse, 1878)

Diagnosis. Lyponiini contains the single genus Lyponia, and therefore its diagnosis is the same as the genus.

Genus Lyponia Waterhouse, 1878

(Figs 13-14, 42, 45, 48, 56, 61, 72, 91, 129)

Lyponia Waterhouse, 1878: 99.

Ponyalis Fairmaire, 1899: Bocák, 1999:85.

Type species: Lyponia debilis Waterhouse, 1878 (original designation).

Diagnosis. Head transverse, almost prognathous, occipital foramen of characteristic shape (Figs 13-14). Tentorial arms long. Mandibles stout, maxillary palpi provided with large securiform, rather oblique terminal palpomere. Terminal segment of labial palpi rather dilated apically, labrum strongly transverse. Male antennae pectinate to filiform, female antennae more or less serrate to filiform. Pronotum subquadrate, with a median impressed line on the disc, scutellum almost square. Elytra slightly widened posteriorly, each elytron with 9 longitudinal costae, reticulate cells strongly transverse in subgenus Ponyalis, subquadtrate in Lyponia s. str. and Weiyangia Bocák. Male genitalia without paramerae, distal portion of phallus often provided with a pair of lateral spines, phallobase annuliform. Female genitalia elongate, valvifers laterally bent, tightly attached to coxites, styli small. Female terminal abdominal sternum provided with short spiculum gastrale.

Distribution. Northern part of the Oriental Region (northern India, Thailand, Laos) and eastern part of the Palaearctic Region (Japan, China, Taiwan).

Comments. Bocák (1999) has recently given a more detailed description of Lyponia in the revision and phylogenetic analysis of the genus.

\section{Tribe Libnetini Bocák \& Bocáková, 1990}

Libnetinina Bocák \& Bocáková, 1990a: 652. (Type genus: Libnetis Waterhouse, 1878).

Diagnosis. Head small, antennae filiform, rarely weakly serrate. Pronotal areolae absent, median longitudinal line usually present in anterior half, posteriorly channelled. Each elytron usually with 4 primary costae, secondary costae and reticulate cells usually absent (pre- sent in Dihammatus and Microlyropaeus). Mesosternum rather trapezoidal or transverse. Male genitalia with paramerae strongly transformed (Figs 123-127), female genitalia with small paraprocts, inner basal margins of coxites emarginate and mutually distant.

Composition. As here understood, Libnetini contain 4 genera: Dihammatus, Libnetis, Libnetisia, and Microlyropaeus. Genera Libnetomorphus Pic and Macrolibnetis Pic, formerly classified with Libnetini (Bocák \& Bocáková, 1990a), are understood as synonyms of Plateros (Platerodinae) and Platerodrilus respectively.

Distribution. Libnetini have largely Oriental and partly Palaearctic distribution: Japan, southern China, Taiwan, the Himalayas, Thailand, Laos, Vietnam, the Great and Little Sundas, Philippines

\section{Genus Dihammatus Waterhouse, 1879}

(Figs 11-12, 27, 41, 43, 55, 63, 74, 94, 123-124, 138)

Dihammatus Waterhouse, 1879: 29.

Type species: Dihammatus cribripennis Waterhouse, 1879 [subsequent designation by Bourgeois (1891)].

Diagnosis. Small lycids with antennomere 3 short, as long as 2, pronotum without carinae, each elytron with 9 weak costae, reticulate cells oval, irregular.

Redescription. Head with small eyes, eye diameter usually shorter than interocular distance, antennae filiform, reaching elytral midlength. Mandibles arcuate, maxillary palpi long, 4-segmented, labial palpi short, 3 -segmented. Both palpi with terminal palpomere provided with irregular distal papillae. Pronotum transverse, widest at basal margin, anterior margin produced forwards, sides elevated. Posterior angles acute, slightly projected laterally. Anterior portion densely punctured, posterior half with very narrow median longitudinal areola. Scutellum weakly emarginate apically. Elytra elongate, subparallel-sided, about 3 times as long as humeral width, slightly wider than pronotum. Each elytron with 9 weak costae, reticulate cells irregular, more or less oval. Mesosternum rather trapezoidal, strongly transverse, wing venation with brace $\mathrm{CuA}_{2}$ present and $\mathrm{AP}_{3+4}$ absent. Abdominal sternum 8 widely emarginate distally, male sternum 9 elongate. Female terminal sternum with spiculum gastrale as long as the segment. Legs slender, compressed, tibiae straight, their spurs small, acute, trochanters elongate, hind trochanters slightly apically widened, of trianguloid shape, tarsomeres 2-4 lobed. Male genitalia with dorsally, and sometimes also ventroproximally fused paramerae, phallobase elongate (Figs 123, 124). Female genitalia provided with stick-formed valvifers, separate from each other, paraprocts present, reduced. Besides proximal vaginal glands, female genitalia provided with additional pair of tubular glands joining vagina near vulva (colleterial glands). Body length: $3.4-4.7 \mathrm{~mm}$, humeral width: $1-1.2 \mathrm{~mm}$.

Type material. Holotype ( $\delta$ ) of Dihammatus cribripennis Waterhouse, Java, Bowring (BMNH).

Distribution. SW China (Yunnan), Nepal, Assam, Vietnam, Malaysia, Sumatra, Java, Borneo, Taiwan, Philippines. 


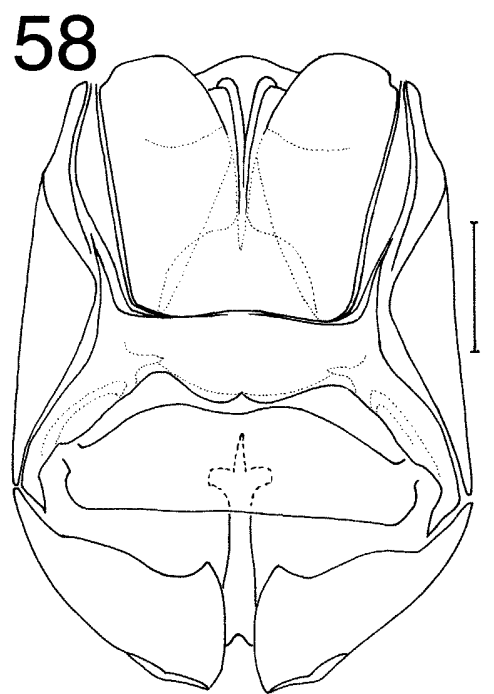

59

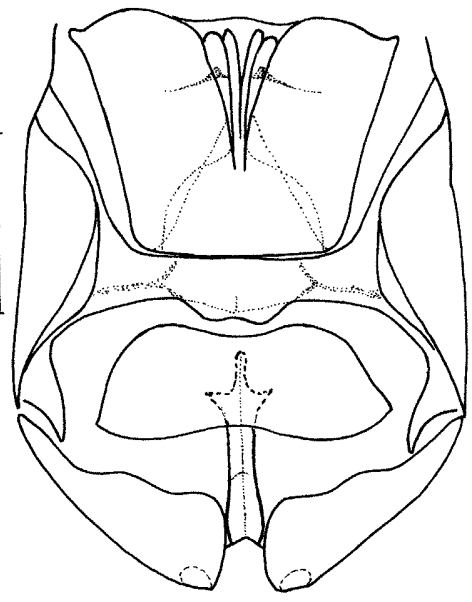

60

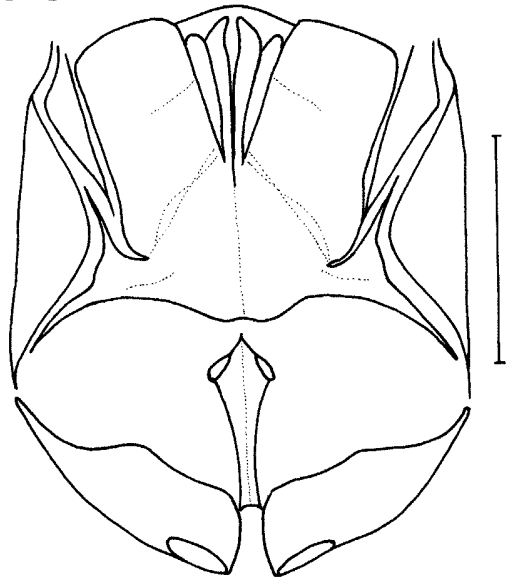

65
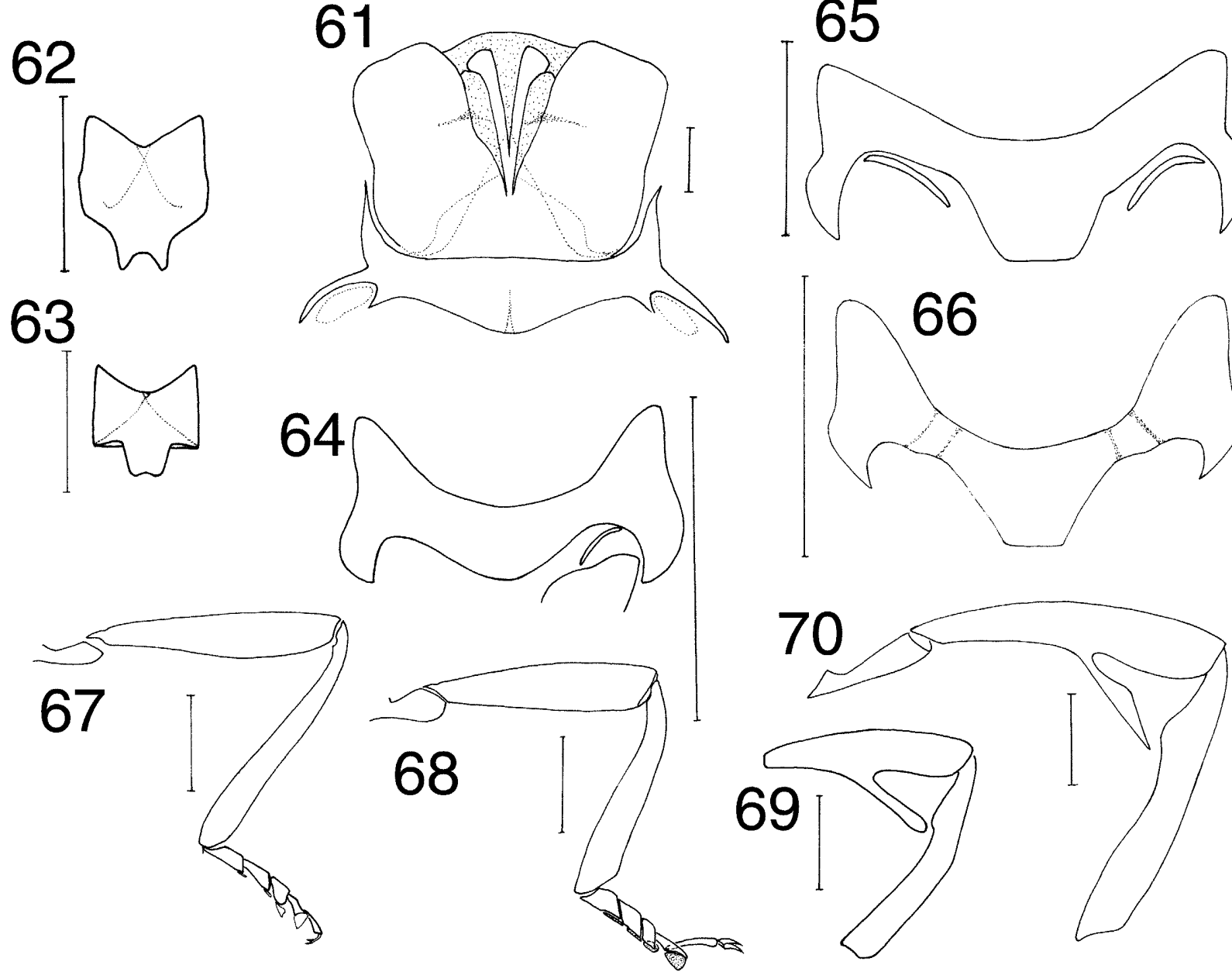

Figs 58-70. 58-61: Thorax, dorsal view. 58 - Plateros planatus, 59 - Dihammatus sp.; 60 - Libnetis piceovittatus; 61 - Lyponia himalejica; 62-63: Scutellum. 62 - Libnetis piceovittatus; 63 -Dihammatus sp.; 64-66: Mesosternum. 64 - Fernandum minutum; 65 - Calolycus calanticatus; 66 - Falsocalleros moleculus. 67-70: Hind leg. 67 - Teroplas oculatus; 68 - Microlycus mexicanus sp. n.; 69 - Cavoplateros dentatus; 70 - Cavoplateros spinipes. Scale $=0.5 \mathrm{~mm}$.

\section{Genus Libnetis Waterhouse, 1878}

(Figs 9-10, 28, 40, 46, 50-51, 54, 60, 76, 125a-b, 141-142) Libnetis Waterhouse, 1878: 104.
Type species: Libnetis pumilio Waterhouse, 1878 (by monotypy).

Libnetomimus Kleine, 1927: 1, syn. n.

Type species: Libnetomimus setosus Kleine, 1927 (original designation). 

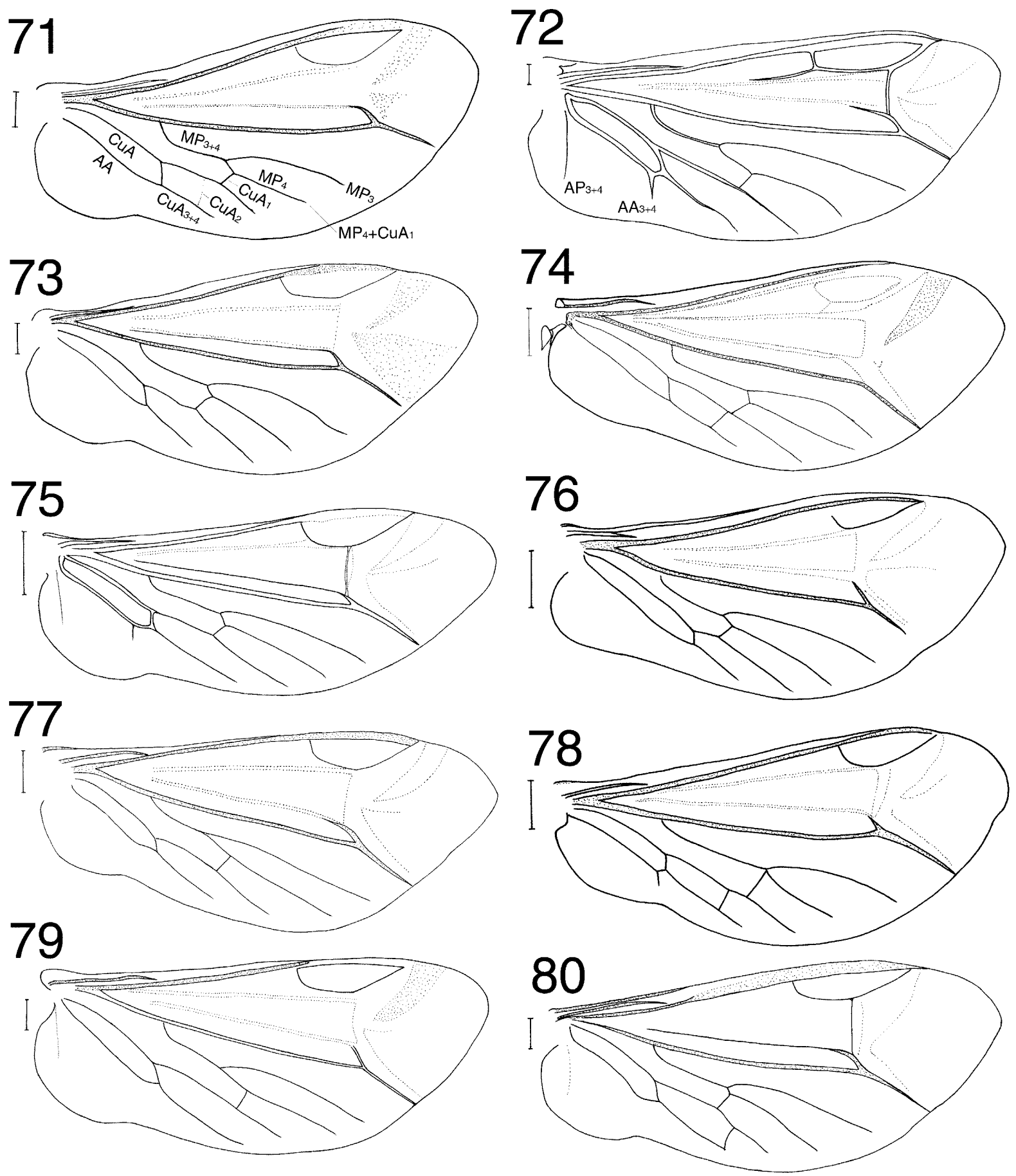

Figs 71-80: Wing venation. 71 - Calolycus calanticatus; 72 - Lyponia himalejica; 73 - Teroplas fusculus; 74 - Dihammatus sp.; 75 - Plateros particularis (Pic); 76 - Libnetis piceovittatus; 77 - Cavoplateros spinipes; 78 - Libnetisia atronotata; 79 - Plateros planatus; $80-$ Falsocalleros particularis. Scale $=0.5 \mathrm{~mm}$.

Diagnosis. Small lycids with rather prolonged mouthparts, reduced mandibles, antennomere 3 long, each elytron with 4 longitudinal costae, secondary costae and reticulate cells absent.

Redescription. Body usually partly brown or yellow. Head with large eyes, eye diameter as long as or longer than interocular distance. Antennae filiform in both sexes, in some species one of antennomeres 4-7 provided with a short lamella. Antennae reaching elytral midlength, antennal tubercles conspicuous. Antennomere 3 long, as long as $3 / 4$ of antennomere 4 . Mouthparts elongate, mandibles reduced, almost trianguloid. Maxillary palpi long, 4-segmented, labial palpi short, 3-segmented, both palpi with terminal palpomeres apically pointed. Pronotum trapezoidal, transverse, widest at basal margin, anterior margin slightly produced forwards, sides elevated. Anterior portion medially elevated and strongly punctured. Median longitudinal line channelled at base, forming 
small longitudinal areola. Posterior angles acute, projected obliquely backwards. Scutellum with a shallow arcuate apical notch. Elytra elongate, subparallel-sided, 2.6-3.3 times as long as humeral width and slightly wider than pronotum. Each elytron with 4 weak costae, secondary costae entirely absent. Reticulate cells absent, elytra densely punctured. Mesosternum strongly transverse, wing venation with $\mathrm{AP}_{3+4}$ absent. Male terminal sternum provided with proximal enlargements to which projections of tergum 9 are attached. Legs very slender, compressed. Tibiae straight, apical spurs small, slender and acute, trochanters long. Tarsomere 1 not lobed, tarsomere 2 only with hardly visible remnant of its lobe, lobes of tarsomeres 3 and 4 large. Male genitalia with short phallobase, paramerae shortened usually as long as half of phallus, ventrobasally fused. Phallus tapering to apex, entirely opened ventrally. Female genitalia short, coxites medially emarginate, valvifers basally widened, these enlargements ventromedially approached. Body length: $3.4-5.3 \mathrm{~mm}$; humeral width: $1-1.6 \mathrm{~mm}$.

Type material. Syntype of Libnetis pumilio, of (BMNH) "Ceylon, Thwaites" (bearing Waterhouse's label $\not$ ); syntype,,+ , the same data (BMNH). Holotype of Libnetomimus setosus Kleine, ‘ "Luzon, Mt. Makiling, Baker" (ZMPA).

Distribution. S China, Thailand, Laos, Vietnam, Burma, Nepal, India, Sri Lanka, Malaysia, the Great Sundas, Bali, Taiwan, Philippines.

Comments. Kleine (1927) established the genus Libnetomimus on the basis of the presence of a lamella on antennomere 7 . Because of this character appears several times in different species groups of Libnetis (lamella can be present on different antennomeres) it cannot be supposed to be a synapomorphy, but a multiple parallelism.

\section{Genus Libnetisia Pic, 1921}

(Figs 78, 85-86, 127)

Libnetisia Pic, 1921a: 1.

Type species. Libnetisia atricornis Pic, 1921 (original designation).

Diagnosis. Small lycids with short mouth-parts, each elytron with 4 costae, reticulate cells absent. Paramerae incorporated into phallus (Fig. 127), shorter than half of phallus.

Redescription. Head with small eyes, interocular distance 1.5 times as long as eye diameter, antennae filiform, long, reaching apical third of elytra, antennomere 3 long, $1 / 3$ shorter than 4 . Mandibles slender, arcuate, maxillary palpi long, with terminal palpomere parallel-sided, slightly apically securiform, labial palpi 3-segmented. Pronotum trapezoidal, transverse, widest at base, anterior margin semicircularly produced forwards, sides elevated. Posterior angles acute, projected obliquely backwards. Anterior half of pronotum strongly punctured, provided with median longitudinal carina, pronotum medially weakly channelled in basal half. Scutellum with shallow apical notch. Elytra elongate, subparallel-sided, about 3 times as long as humeral width. Each elytron with 4 weak costae, reticulate cells and secondary costae absent, elytra finely punctured. Mesosternum more or less trapezoidal, transverse, wing venation with short vein $\mathrm{AP}_{3+4}$ some- times present. Abdominal sternum 8 with an arcuate distal emargination, male sternum 9 elongate, twice laterally emarginate in proximal portion. Legs rather stouter than in Libnetis, tibiae straight, their spurs small, trochanters elongate, hind trochanters slightly trianguloid, tarsomeres 1-4 lobed. Male genitalia rather dorsoventrally flattened apically, paramerae strongly reduced, shorter than half of phallus, phallobase short (Fig. 127).

Body length. 5.3-5.5 mm, humeral width: $1.3-1.4 \mathrm{~mm}$.

Type material. Holotype (o) of Libnetisia atronotata Pic, 1923, "Chapa", without other data (MNHN).

Distribution. SW China (Yunnan), Assam, India, Vietnam, Sumatra, Borneo, Philippines.

Comments. Unfortunately, it was not possible to examine the type species of the genus Libnetisia atricornis because its type specimen was not found in $\mathrm{M}$. Pic's collection (MNHN). The only Libnetisia type specimen found was that of Libnetisia atronotata. Therefore, the concept of Libnetisia as here understood corresponds to it.

\section{Genus Microlyropaeus Pic, 1929}

Microlyropaeus Pic, 1929: 4.

Type species. Microlyropaeus notaticollis Pic, 1929 (by monotypy).

Diagnosis. Lycids resembling Dihammatus in having short antennomere 3 that is of the same length as 2 . On the other hand, Kasantsev (1997a) examined the structure of male genitalia that are similar to those of Libnetis.

Distribution. Sumatra.

Comments. Unfortunately, it was not possible to examine the only known specimen of the genus because its lectotype has been loaned for several years. Therefore, Microlyropaeus Pic could not been included into the phylogenetic analysis. Kasantsev (1997a) examined its lectotype and supposed Microlyropaeus to have rather intermediate position between the genera Dihammatus and Libnetis. Consequently, here it is tentatively classified within Libnetini incertae sedis.

\section{Tribe Platerodini Kleine, 1928}

Platerodinae Kleine, 1928: 222.

Diagnosis. Small lycid beetles, head partly concealed under pronotum, antennal tubercles inconspicuous, antennae mostly filiform, in some species serrate to pectinate in males and serrate in females. Pronotum usually transverse, rather subpentagonal, widest at base. Disc convex, weakly elevated dorsally, without carinae, median longitudinal line posteriorly channelled, forming a small median depression at basal margin. Margins narrowly reflexed, sides more broadly. Scutellum oblong, apically impressed. Elytra with primary and secondary costae usually equal in strength. Each elytron with 9 longitudinal costae, in Falsocalleros five intercostae present only basally and primary costae 1 and 3 apically reduced. Spiculum gastrale of female terminal sternum absent. Male genitalia with paramerae absent (Plateros and Cavoplateros) or strongly shortened (Falsocalleros), only Teroplas having paramerae long. Female genitalia short, 

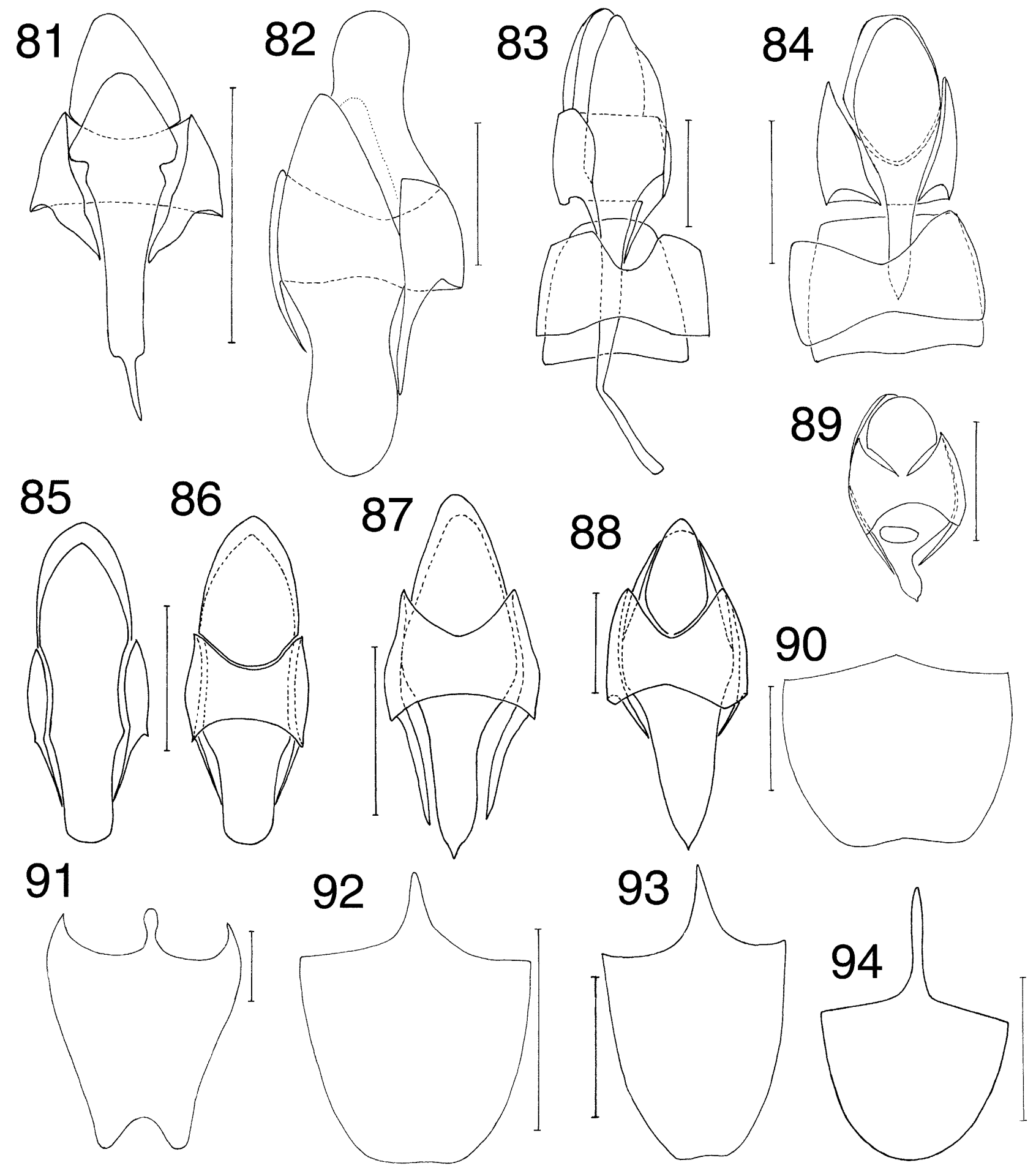

Figs 81-94. 81-89: Terminal abdominal segment of male. 81 - Plateros atroviolaceus; 82 - Calolycus calanticatus; 83 - Melaneros acuticollis; 84 - Cavoplateros spinipes; 85, 86 - Libnetisia atronotata; 87 - Teroplas fusculus; 88 - Plateros brasiliensis (Lucas); 89 - Cavoplateros dentatus; 90-94: Female terminal sternum. 90 - Calolycus calanticatus; 91 - Lyponia himalejica; 92 Microlycus minutus; 93 - Microlycus mexicanus sp. n.; 94 - Dihammatus sp. Scale $=0.5 \mathrm{~mm}$.

inner basal margins of coxites approached to each other, valvifers short, widened basally. Female genital ducts with vaginal glands widely attached to vagina at its apex.

Composition. Platerodini as here understood contain the genera Teroplas, Falsocalleros, Plateros and Cavoplateros.

\section{Genus Teroplas Gorham, 1884}

Teroplas Gorham, 1884: 243.

Type species: Calocladon fusculus Gorham, 1881 (by monotypy).

Diagnosis. Head with large eyes, partly hidden by pronotum, eye diameter 1.7 times to twice as long as intero- 

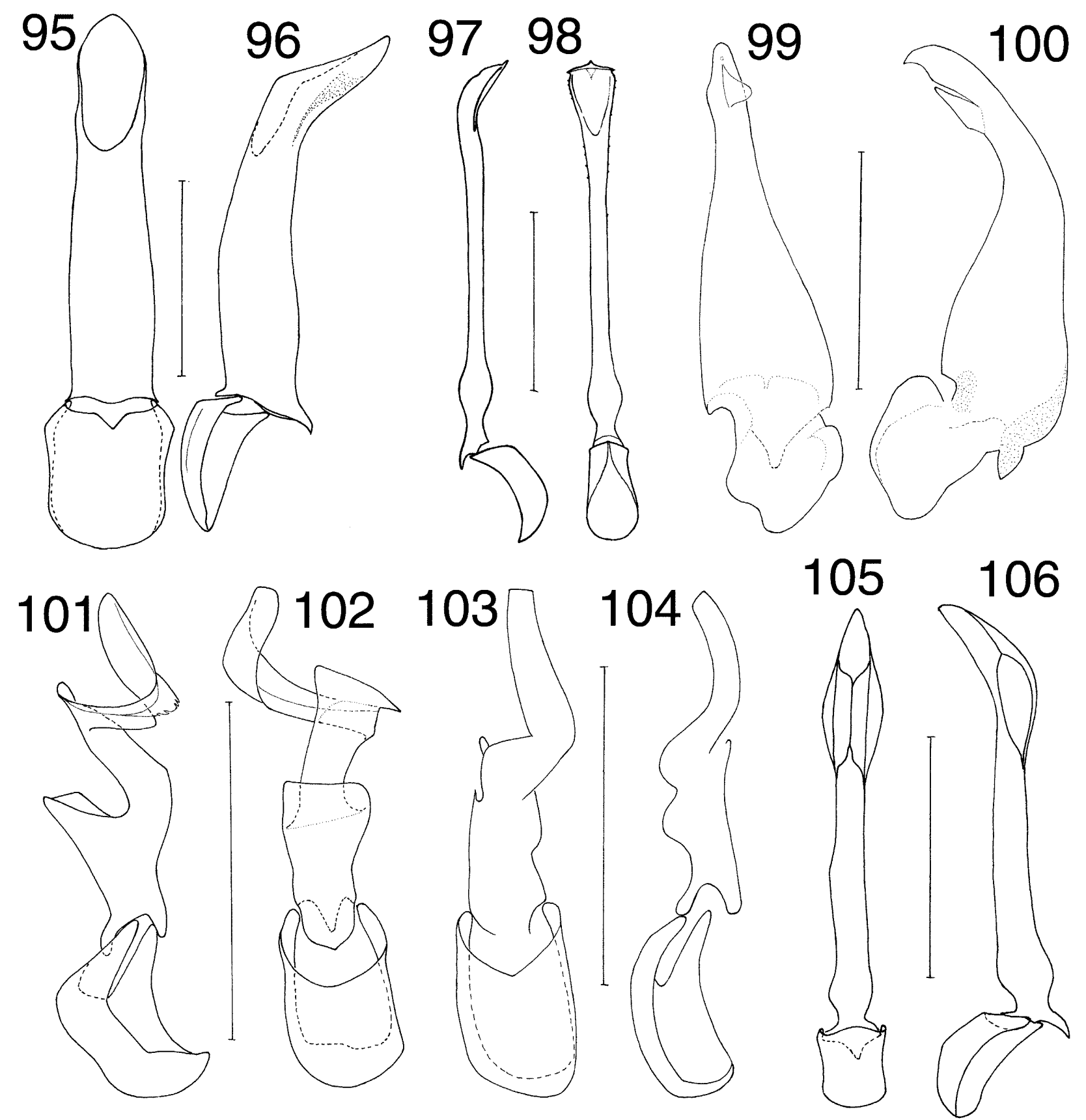

Figs 95-106. Male genitalia. 95-96: Plateros puniceus; 97-98: Plateros malaccanus; 99-100: Plateros atroviolaceus; 101-102: Cavoplateros dentatus; 103-104: Cavoplateros spinipes; 105-106: Plateros cephalotes (Pic). Scale $=0.5 \mathrm{~mm}$.

cular distance, female eyes smaller. Antennae of both sexes long, reaching at least apical quarter of elytra. Male antennae serrate to pectinate, female antennae serrate. Antennomere 1 stout and constricted basally, 2 small, 3 about 1.6 times shorter than 4, antennomeres 4-10 subequal in length. Mandibles slender, arcuate, apically pointed. Maxillary palpi long, with palpomere 2 elongate, terminal palpomere securiform. Labial palpi short, with terminal palpomere apically dilated. Pronotum trapezoidal, transverse, widest at basal margin, anterior margin strongly produced forwards, weakly emarginate, posterior angles projected obliquely backwards. Scutellum almost square, weakly emarginate apically. Elytra almost parallel-sided, more than 3 times as long as humeral width. Each elytron with 9 weak costae, reticulate cells oval, mesosternum trapezoidal. Legs slender, compressed, trochanters elongate, tibiae straight, their spurs small. Lobes of tarsomeres 1 and 2 strongly reduced, those of tarsomeres 3-4 wide. Male genitalia with long ventrobasally fused paramerae, phallus with apical opening weakly constricted before apex, median portion of phallus with two stick-formed projections. Female genitalia short, styli long, slightly longer than coxites, valvifers laterally bent, freely attached to coxites, spiculum gastrale absent.

Distribution. Nicaragua, Panama. 
Composition. This, formerly monotypic genus, currently comprises two species.

\section{Teroplas fusculus (Gorham, 1881)}

(Figs 17, 32, 57, 73, 87, 112, 134)

Diagnosis. Male antennae provided with long lamellae, female antennae serrate, paramerae with straight apices, distal orifice of phallus slightly constricted before apex.

Redescription. Body dark brown to black, lateral belts of pronotum and humeral portion of primary costa 3 yellow.

§. Head with large eyes, partly hidden by pronotum, eye diameter 1.7 times interocular distance. Antennae long, reaching apical fifth of elytra, strongly ramose, with antennomere 1 stout and constricted basally, 2 small, 3 about 1.6 times shorter than 4 , provided with a branch as long as its length, antennomeres 4-10 subequal in length, with long branches (about 1.5-2 times as long as their length. Mandibles slender, arcuate, apically pointed. Maxillary palpi long, palpomere 2 elongate, terminal palpomere securiform. Labial palpi short, terminal palpomere apically dilated. Pronotum trapezoidal, transverse, widest at basal margin, anterior margin strongly produced forwards, sides elevated, weakly emarginate, posterior angles projected obliquely backwards. Scutellum almost square, apical margin weakly emarginate. Elytra almost as wide as pronotal base, slightly divergent backwards, widest in apical third, about 3 times as long as humeral width. Each elytron with 9 weak costae, reticulate cells oval. Mesosternum trapezoidal, wing venation with $\mathrm{AP}_{3+4}$ absent. Legs slender, compressed, trochanters elongate. Tibiae straight, their spurs small, slender, and acute. Male genitalia with long paramerae, their apex straight and obtuse. Phallus with apical opening weakly constricted before apex.

$\uparrow$. Female eyes smaller, as long as interocular distance, antennae serrate. Female genitalia short, styli long, slightly longer than coxites, valvifers laterally bent, freely attached to coxites. Female terminal sternum without spiculum gastrale. Body length: $6.2-6.5 \mathrm{~mm}$, humeral width: $1.9-2.25 \mathrm{~mm}$.

Type material. Holotype, $₫$, "Nicaragua, Chontales, T. Belt" (BMNH).

Other material. Panama, Bugaba, $800-1500 \mathrm{ft}$, Champion leg., 1 of, 1 ㅇ(BMNH).

Distribution. Central America.

Teroplas oculatus sp. $\mathbf{n}$.

(Figs 18, 33, 67, 113-114)

Diagnosis. It differs from $T$. fusculus in having larger eyes, the male antennae serrate, and in the shape of aedeagus (paramerae divergent distally, apical opening of phallus gradually narrowed).

Description. $\widehat{\sigma}$. Body dark brown to black, lateral margins of pronotum and trochanters yellow. Head with large hemispherically prominent eyes, eye diameter 2.3 times as long as interocular distance. Antennae very long, reaching apical tenth of elytra, strongly and acutely serrate, antennomere 1 stout and constricted at base, 2 small and narrow, 3 about 1.6 times shorter than 4 , antenno- meres 4-10 subequal in length but diminishing width in apical antennomeres, 11 narrow and elongate. Mandibles slender, arcuate, apically pointed. Maxillary palpi long, palpomere 2 elongate, terminal palpomere securiform. Labial palpi short, terminal palpomere apically dilated. Pronotum trapezoidal, rather transverse, widest at basal margin, anterior margin strongly produced forwards medially, sides elevated, weakly emarginate, posterior angles strongly projected laterally, obtuse. Scutellum with shallow arcuate apical notch. Elytra elongate, subparallelsided, about 3.3 times as long as humeral width and almost as wide as pronotal base. Each elytron with 9 weak costae, reticulate cells oval, transverse raised lines indistinct. Mesosternum trapezoidal, wing venation with short remnant of $\mathrm{AP}_{3+4}$. Legs slender, compressed, trochanters elongate, tibiae straight, and their spurs small, slender and acute. Sternum 8 weakly apically emarginate. Male genitalia with paramerae weakly divergent apically, their apices almost pointed. Distal opening of phallus gradually narrowed. Body length: $6.05 \mathrm{~mm}$, humeral width: $1.45 \mathrm{~mm}$. Female unknown.

Etymology. The name "oculatus" refers to large eyes of the male.

Type material. Holotype, $\precsim$,Panama: V. de Chiriqui, 4000-6000 ft., Champion" (MNHN).

Distribution. Panama.

\section{Genus Falsocalleros Pic, 1933}

Falsocalleros Pic, 1933: 110.

Type species. Falsocalleros particularis Pic, 1933 (by monotypy).

Pseudoplateros Green, 1951: 18, syn. n.

Type species. Pseudoplateros moleculus Green, 1951 (original designation).

Diagnosis. Head with small eyes, interocular distance at least 1.5 times as long as eye span. Antennae filiform, short, reaching elytral third. Antennomere 3 trianguloid, $1 / 3$ shorter than 4 . Pronotum rather trapezoidal, transverse, widest at basal margin, anterior margin slightly produced forwards, posterior angles divergent obliquely backwards. Scutellum with shallow arcuate apical notch. Elytra elongate, each elytron with 4 primary costae, costa 1 and 3 apically reduced. Secondary costae present basally, reticulate cells transverse, mesosternum trapezoidal. Wing venation with brace $\mathrm{CuA}_{1}$ attached to $\mathrm{MP}_{3+4}$ shortly after its bifurcation, second $\mathrm{CuA}$ field closed by brace $\mathrm{CuA}_{2}$, vein $\mathrm{AP}_{3+4}$ absent. Legs compressed, tibiae straight, trochanters short, spiculum gastrale absent. Male genitalia provided with stick-formed phallus, paramerae as long as third of phallus, phallobase $1 / 3$ shorter than paramerae. Female genitalia short, inner proximal margins of coxites approached to each other, valvifers short, with widened bases, proctiger elongate. Vagina long, ductus receptaculi spiral.

\section{Distribution. Costa Rica, U. S. A.: Texas.}

Composition. This formerly monotypic genus currently comprises two species.

Comments. Genera Falsocalleros and Pseudoplateros are the only Platerodini taxa having primary elytral costae elevated (ch 1). Also other characters are in such congru- 

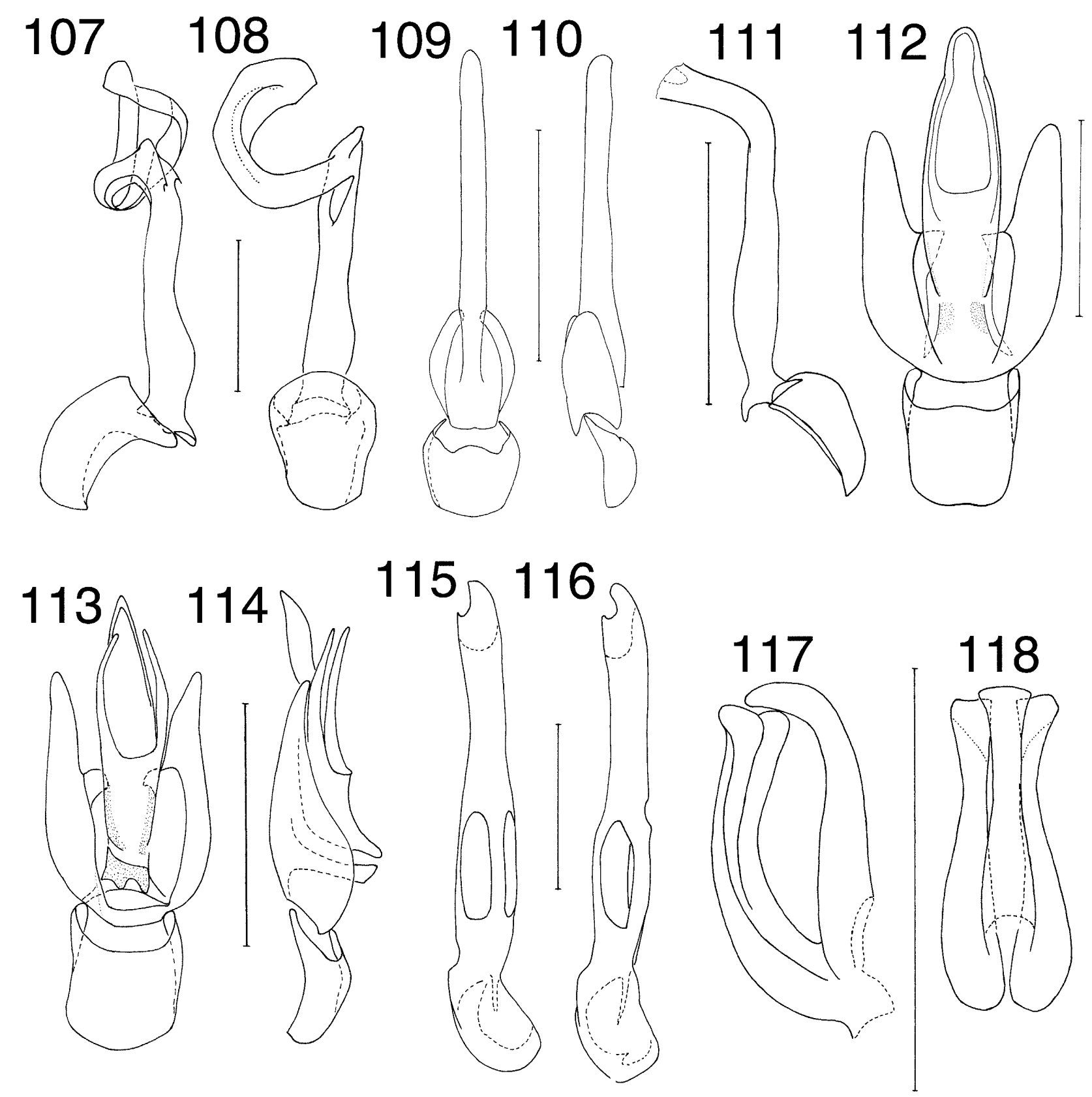

Figs 107-118. Male genitalia. 107-108: Plateros particularis (Pic); 109-110: Falsocalleros moleculus; 111 - Plateros punctipennis (Waterhouse); 112 - Teroplas fusculus; 113-114: Teroplas oculatus sp. n.; 115-116: Melaneros acuticollis; 117-118: Subdihammatus curvus. Scale $=0.5 \mathrm{~mm}$.

ence that even species identity is suspected, however, this cannot be solved until both sexes from the two species are known. Therefore, only the synonymization of Pseudoplateros to Falsocalleros is made here.

Falsocalleros particularis Pic, 1933

(Figs 5, 26, 80, 135)

Falsocalleros particularis Pic, 1933: 110.

Diagnosis. Elytra with strongly reduced secondary costae, transverse costae irregular, primary costae 1 and 3 apically reduced.

Redescription. $\odot$. Body black, only pronotum yellow. Head with small eyes, interocular distance 2.2 times eye span. Antennal tubercles small, antennae filiform, short, reaching elytral third. Antennomere 3 trianguloid, 1/3 shorter than 4. Pronotum rather trapezoidal, transverse, widest at basal margin, anterior margin slightly produced forwards, posterior angles divergent obliquely backwards. Scutellum with shallow arcuate apical notch. Elytra elongate, about 3.5 times as long as humeral width and by $1 / 6$ wider than pronotum. Each elytron with 4 primary costae, with costa 1 and 3 apically reduced. Secondary costae almost absent, their remnants present basally. Reticulate cells transverse, poorly defined, mesosternum trapezoidal. Wing venation with brace $\mathrm{CuA}_{1}$ attached to $\mathrm{MP}_{3+4}$ shortly after its bifurcation. Legs compressed, tibiae straight, trochanters short. Female genitalia short, inner proximal margins of coxites approached to each other, valvifers 

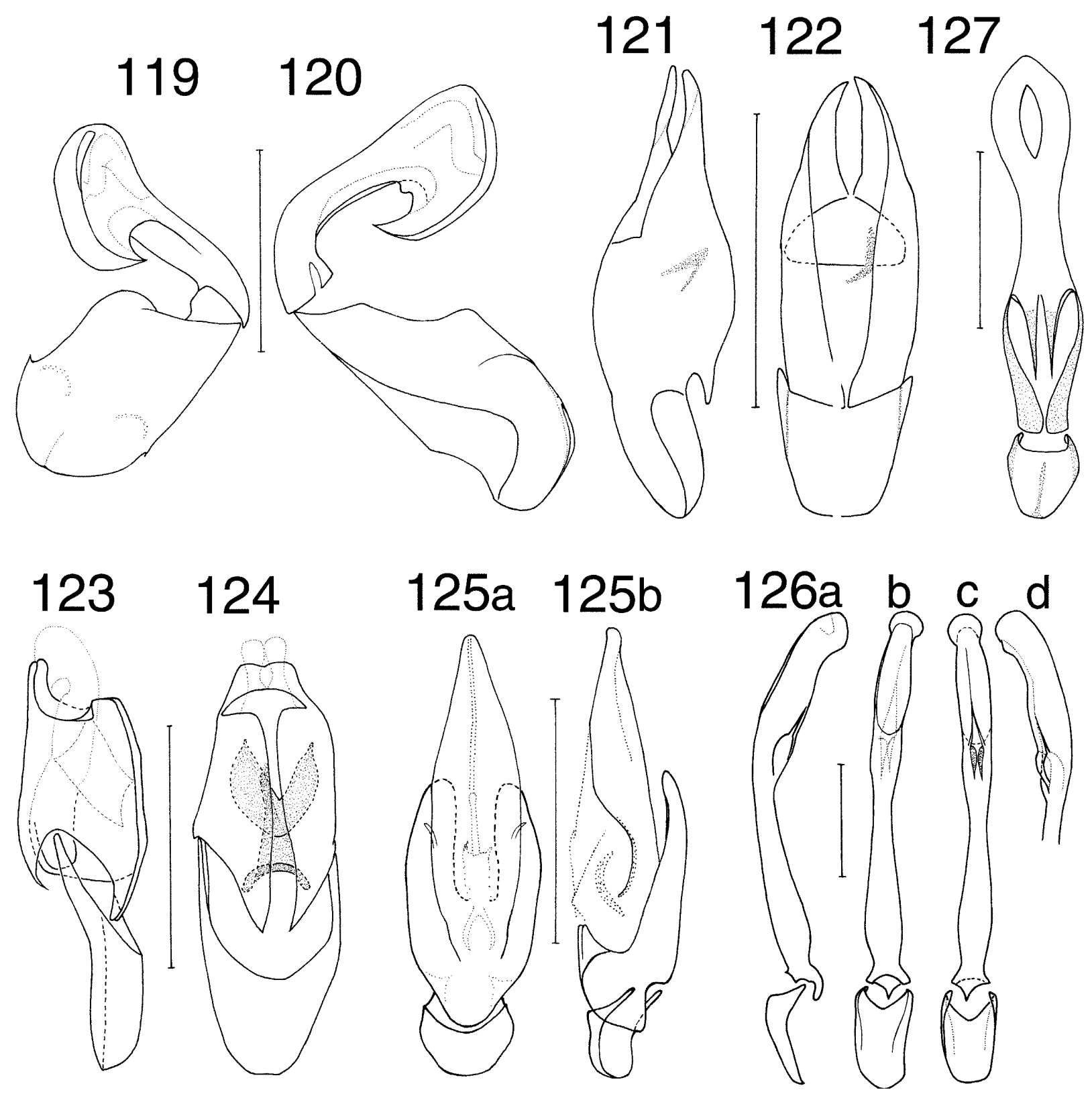

Figs 119-127. Male genitalia. 119-120: Calolycus calanticatus; 121-122: Fernandum minutum; 123-124: Dihammatus cribripennis; 125a-b: Libnetis setosus; 126a-d: Plateros brasiliensis (Lucas); 127 - Libnetisia atronotata. Scales $=0.5 \mathrm{~mm}$; scales for Figs 121-122: $0.25 \mathrm{~mm}$.

short, with widened bases, proctiger elongate. Vagina long, ductus receptaculi spiral. Male unknown.

Type material. Holotype of Falsocalleros particularis Pic, ㅇ, "Südamerika, Vulkan Irazu, $2800-3000$ m, Costa Rica, F. Nevermann, 15. I. 1926" (ZMPA).

Distribution. Costa Rica.

Falsocalleros moleculus (Green, 1951) comb. n. (Figs 66, 109-110)

Pseudoplateros moleculus Green, 1951: 18.

Diagnosis. Secondary elytral costae almost absent, transverse costae irregular, primary costae 1 and 3 apically reduced, aedeagus with short paramerae.

Redescription. $\delta$. Body black, pronotum mostly yellow. Head with small eyes, interocular distance 1.55 times as long as eye span. Antennal tubercles small, antennae short, reaching elytral third. Antennomere 1 stout and constricted basally, 2 small, 3 trianguloid, 1/3 shorter than 4. Pronotum rather trapezoidal, transverse, widest at basal margin, anterior margin slightly produced forwards, posterior angles divergent obliquely backwards. Scutellum with shallow arcuate apical notch. Elytra elongate, about 3.5 times as long as humeral width and by $1 / 6$ wider than pronotum. Each elytron with 4 primary costae, with costa 1 and 3 apically reduced. Secondary costae almost absent, their remnants present basally. Reticulate cells transverse, irregular. Mesosternum trapezoidal. Wing venation with brace $\mathrm{CuA}_{1}$ attached to $\mathrm{MP}_{3+4}$ after its bifurcation. Abdominal sternum 8 with widely trianguloid distal emargination about 2.5 times as wide as deep, 
sternum 9 long. Legs with stout sterna and tibiae, compressed, tibial spurs small, trochanters short, trianguloid. Aedeagus with short paramerae, as long as third of phallus. Female unknown. Body length: $3.8 \mathrm{~mm}$, humeral width: $1.3 \mathrm{~mm}$.

Type material. Holotype of Pseudoplateros moleculus Green, $\_$, U. S. A.: Texas, Pecos, 15. V. 1927, J. O. Martin leg. (CASC).

Distribution. U. S. A.: Texas.

\section{Genus Plateros Bourgeois, 1879}

(Figs 6-8, 15, 16, 23, 25, 29-31, 38, 39, 44, 47, 49, 52, 53, 58, $75,79,81,88,95-100,105-108,111,126 \mathrm{a}-\mathrm{d}, 131,133$, 135-137, 139)

Plateros Bourgeois, 1879: 19; Kleine, 1933: 90; Green, 1953; Nakane, 1969.

Type species. Eros brasiliensis Lucas, 1857 [subsequent designation by Zaragoza (1999)].

Melaneros Fairmaire, 1877: Bocák \& Bocáková, 1992: 255;

Bocáková 1997a, 1997b.

Calleros Gorham, 1881: 25, syn. n.

Type species. Calleros puniceus Gorham, 1881 (original designation).

Calloplateros Pic, 1923: 30, hors texte, syn. n.

Type species. Calloplateros particularis Pic, 1923 (by monotypy).

Costatoplateros Pic, 1949: 5, syn. n.

Type species. Plateros (Costatoplateros) fortecostatus Pic, 1949 (by monotypy).

Ditoneces Waterhouse, 1879: 31, syn. n.

Type species. Lycus (gen. 17) punctipennis Waterhouse, 1878 (original designation).

Cautirodes Pic, 1921a: 3, hors texte, syn. n.

Type species. Ditoneces (Cautirodes) malaccanus Pic, 1921 (by monotypy).

Graciloplateros Pic, 1921: Bocáková, 1997a: 181.

Libnetomorphus Pic, 1921a: 2, hors texte, syn. n.

Type species. Libnetomorphus cephalotes Pic, 1921 (original designation).

Microplateros Pic, 1921a: 2, hors texte, syn. $\mathbf{n}$.

Type species. Microplateros diversithorax Pic, 1921 (original designation).

Planeteros Gorham, 1883: 591, syn. n.

Type species. Planeteros ochropterus Gorham, 1883 (by monotypy).

Tolianus Pic, 1921a: 3, hors texte, syn. n.

Type species. Tolianus diversithorax Pic, 1921 (by monotypy). Melampyrus Waterhouse, 1879: 30, syn. n.

Type species. Lycus (gen. 19) alternans Waterhouse, 1878 (original designation).

Falsotrichalus Pic, 1921: Bocák, 1998: 199.

Diagnosis. Antennae filiform to flabellate, antennomere 3 broader than 2, at least 1.3 times longer than antennomere 2. Pronotum transverse, without carinae, median longitudinal line channelled basally, forming minute areola at posteromedian margin. Each elytron with 9 weak, mostly equally elevated costae, reticulate cells subquadrate. Mesosternum trianguloid, male abdominal sternum 8 feebly emarginate distally. Spiculum gastrale absent. Legs slender, tibiae straight, simple. Male genitalia without paramerae, phallus ventrobasally emarginate, provided with a dorsoproximal projection. Female genitalia provided with short basally widened valvifers, coxites ventromedially approached, styli almost as long as coxites.

Redescription. Form elongate, parallel-sided, head small, partly hidden by pronotum, antennal tubercles weak, eyes varying in size. Antennae filiform to flabellate, antennomere 1 stout, basally constricted, 2 small. Antennomere 3 broader, wider than 2, usually long, at least 1.3 times longer than 2 , its length almost as long as 4 to 3 times shorter than 4 . Antennomeres 4-10 elongate, gradually slenderer apically. Labrum transverse, feebly emarginate, mandibles arcuate, maxillary palpi short, 4-segmented, gradually broader distally, terminal palpomere slightly widened apically, with oblique apex. Labial palpi short, 3-segmented, with terminal palpomere trianguloid. Pronotum transverse, subpentagonal, widest at basal margin, anterior margin produced forwards, sides elevated, anterior angles often rounded, posterior ones acute and divergent obliquely backwards. Pronotum without carinae, usually with lateral folds, median longitudinal line channelled basally, forming minute areola at posteromedian margin. Scutellum almost square, with shallow arcuate apical notch. Elytra elongate, parallelsided, 3-4 times longer than humeral width, slightly wider than pronotum. Each elytron with 9 weak costae, reticulate cells oval to subquadrate, more or less irregular. Mesosternum trianguloid, wing venation with brace $\mathrm{CuA}_{2}$ and $\mathrm{AP}_{3+4}$ absent. Male abdominal sternum 8 with a weak arcuate distal emargination, sternum 9 elongate. Spiculum gastrale absent. Legs slender, compressed, tibiae straight, distal spurs small, slender and acute, trochanters elongate, tarsomeres 1-4 lobed. Male genitalia without paramerae, phallus semicircularly ventrobasally emarginate, provided with a short dorsoproximal projection, basal portion of phallus constricted. Apical portion of phallus often provided with various projections, phallobase mostly short. Female genitalia with short basally widened valvifers, coxites approached to each other by trianguloid ventroproximal projection, closely attached to valvifers and provided with styli distally. Larvae with tripartite dorsum (Miller, 1997).

Type material. Neotype of Plateros brasiliensis (Lucas), ‡, "Bras., Sao Paolo, Mráz leg." (NMPC); Holotype of Calleros puniceus Gorham, ${ }^{\star}$, "Guatemala, Tactic, Champion" (BMNH); syntype of Calloplateros particularis Pic, $\diamond$, "Sauter, Bresil" (MNHN), syntype, ㅇ, "Brasilia, Rio Gr. Do Sul, coll. Rich. Hicker" (MNHN); Syntype of Plateros (Costatoplateros) forte-

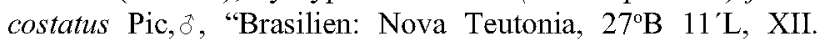
1937, Fritz Plaumann" (MNHN), other syntypes: the same data, XI. 1937, 1, "Brasilia, Rio Gr. Do Sul, coll. Rich. Hicker", 2 ( $(\mathrm{MNHN})$; Holotype of Ditoneces punctipennis Waterhouse, ${ }^{\star}$, "Java, Bowring" (BMNH); Holotype of Ditoneces (Cautirodes) malaccanus Pic, $\partial$, "Perak, Doherty" (MNHN); Syntype of Libnetomorphus cephalotes Pic, ${ }^{\star}$, "Mana Riang, Rana, Palembang, April 90, 2-3000 f, I. Z. Kannegieter" (MNHN), other syntypes, 2 , the same data (MNHN); Holotype of Microplateros diversithorax Pic, o, "Mana Riang, Rana, Palembang, April 90, 2-3000 f, I. Z. Kannegieter" (MNHN); 


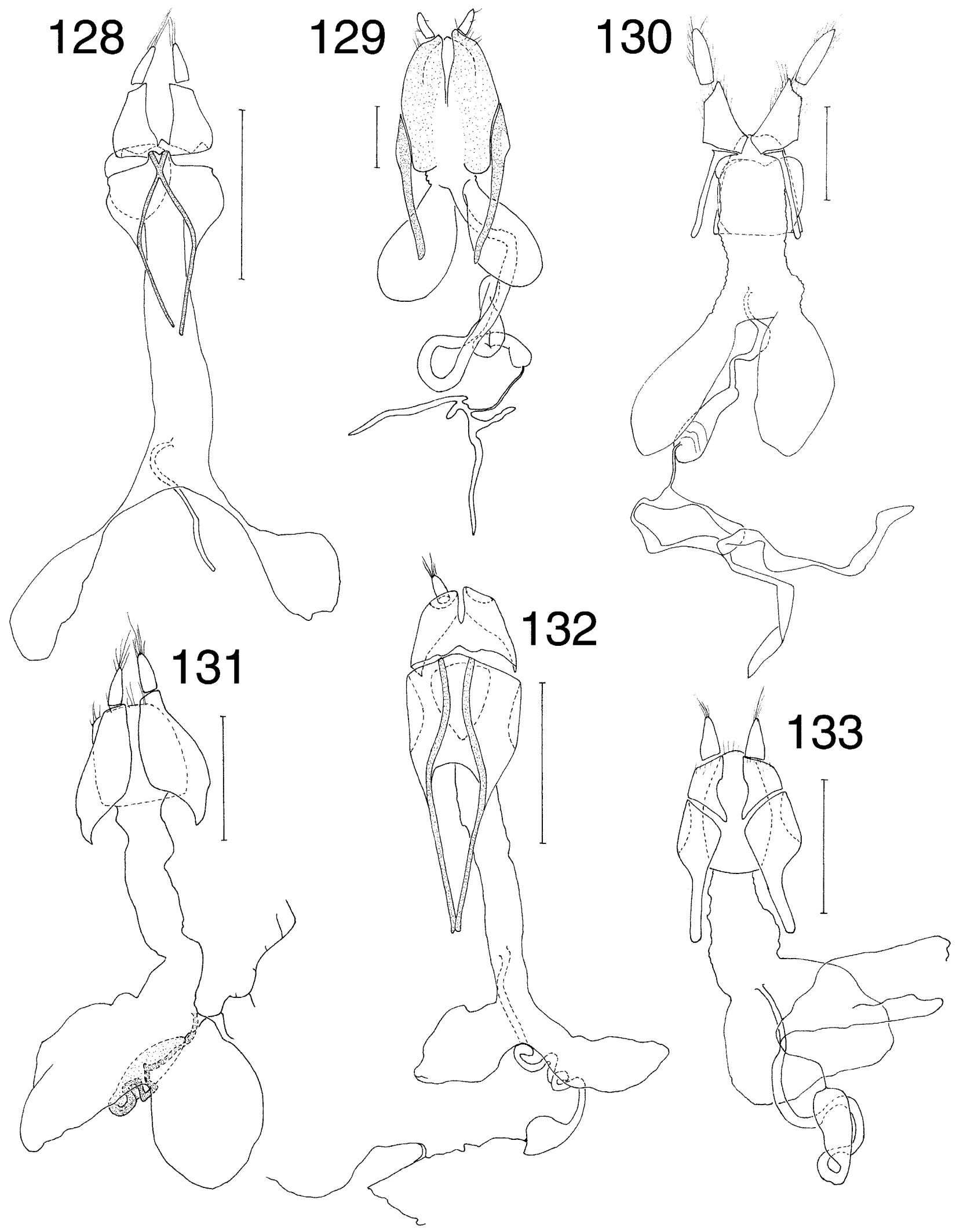

Figs 128-133. Female genitalia. 128 - Microlycus minutus; 129 - Lyponia himalejica; 130 - Calolycus calanticatus; 131 Plateros particularis (Pic); 132 - Microlycus mexicanus; 133 - Plateros planatus. Scale $=0.5 \mathrm{~mm}$.

Holotype of Tolianus diversithorax Pic, o, "Nord Celebes, ToliToli, Nov-Dez 1895, H. Fruhstorfer" (MNHN); Holotype of Melampyrus alternans Waterhouse, o "Sarawak, Wallace" $(\mathrm{BMNH})$.
Other material. Ethiopia: Dint. Harrar, V.-VI. 1904, Citerni lgt., 1 o of Planeteros ochropterus Gorham, det. Pic (MCSN).

Distribution. Nearctic and Neotropical Region, Palaearctic Region: East Asia (Ussuri, Korea, Japan, China), Afrotropical 


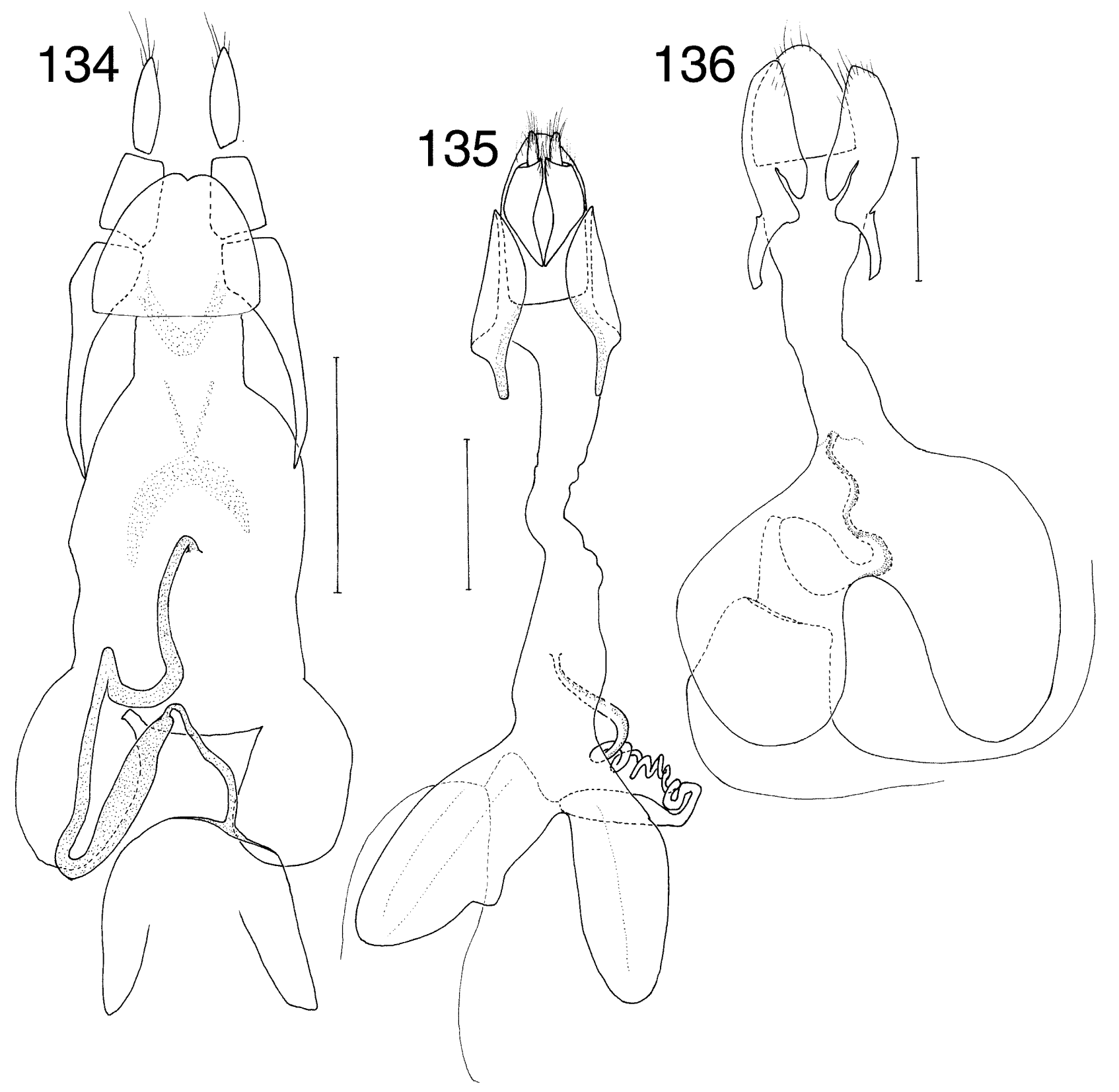

Figs 134-136. Female genitalia. 134 - Teroplas fusculus; 135 - Falsocalleros particularis; 136 - Tolianus diversithorax. Scale = $0.5 \mathrm{~mm}$.

Region, Oriental Region, Australian Region (New Guinea, the Tonga islands, Fidji, Samoa, and northern Queensland in Australia).

Comments. Bourgeois (1891) fixed Melaneros acuticollis Fairmaire, 1877 to be the type species of the genus Melaneros Fairmaire, 1877. Blair (1928) overlooked this fixation, designated Melaneros atroviolaceus Fairmaire, 1877 as type species of Melaneros, and proposed name Samoaneros for the species Melaneros acuticollis. Bocák \& Bocáková (1992) also overlooked Bourgeois's fixation of Melaneros acuticollis as type species of Melaneros, considered Blair's (1928) fixation of the type species Melaneros atroviolaceus for the genus Melaneros to be valid, and consequently they synonymized Plateros Bourgeois, 1879 to Melaneros Fairmaire, 1877. The detection of the fact that Bourgeois (1891) had already fixed Melaneros acuticollis as type species of Melaneros compels me to reinstate the validity of Plateros Bourgeois, 1879.

Eros alatus Newman, 1838 was considered to be the type species of Plateros for long, but Bourgeois (1879) did not included this species in the original description of Plateros. Therefore, subsequent designation (Bourgeois, 1891) of Plateros alatus to be the type species of Plateros is invalid. Consequently, Zaragoza (1999) designated Plateros brasiliensis (Lucas) as type species of Plateros, but he has not prospected its holotype. 


\section{Comments on synonymizations of individual genera.}

Plateros Bourgeois, 1879 is a large, widely distributed genus. After the examination of considerable adult material from all zoogeographic regions, and after several regionally limited species revisions (Bocáková, 1997a, 1997b) of the genus Plateros (as Melaneros), it was apparent that maintenance of several genera as distinct from Plateros is arbitrary. The fusion of Plateros, Calleros, Ditoneces into one genus is also maintained by larval characters (Miller, 1997) - the tripartite larval dorsum seems to be a synapomorphy of the genus Plateros as here understood. Examination of type specimens of all genus-group taxa of Platerodini resulted in many nomenclatural acts.

Calleros Gorham, 1881 was proposed for "small Lycidae allied to Plateros, but differ considerably both in general appearance and, especially, in the long thin antennae". Holotype of the type species - Calleros puniceus Gorham, 1881 has antennae reaching slightly over elytral midlength, which is usual in other Plateros. The other Gorham's distinguishing character - brightly coloured red thoraces and elytra, also occurs in Plateros from other zoogeographic regions. Calleros puniceus has a rather shorter antennomere 3 , but the length is within the range of variation of the other Plateros. Because I found no other distinguishing character, Calleros Gorham, 1881 is synonymized.

Calloplateros Pic, 1923 was proposed for the single species Calloplateros particularis Pic, 1923 which has a slender median longitudinal carina on pronotum. Pic (1923) noticed that Calloplateros is very close to Plateros. If we accept the concept of Calloplateros, the genus Plateros would become paraphyletic having no apomorphic character distinguishing it from Calloplateros, and therefore Calloplateros is synonymized.

Costatoplateros Pic, 1949 was proposed as a subgenus of Plateros Bourgeois, 1879 for the single species Plateros fortecostatus Pic, 1949 on the basis of primary elytral costae more elevated than the secondary ones. This character was observed also in other Plateros like species formerly classified with Melampyrus and Ditoneces. Consistent classification of all species with moderately stronger primary elytral costae in Costatoplateros would result in a polyphyletic assemblage. If we restrict the subgenus Costatoplateros to be monophyletic to the type species, the nominotypical subgenus Plateros would become paraphyletic having no apomorphic character distinguishing it from Costatoplateros, and therefore Costatoplateros is synonymized.

Ditoneces Waterhouse, 1879 was proposed for Plateros-like species having flabellate antennae in males and serrate antennae in females. This character occurs in many other Plateros species. Kleine (1926) already discussed the position of Ditoneces. He stated that its relatedness to Plateros is very close and females cannot be placed to this or that genus. He was not aware of any other distinguishing character except the pectinate antennae in males of Ditoneces while those of Plateros are filiform. Kleine (1926) even states: "Während es bei manchen Lycidengattungen möglich ist, durch Vergleichende Untersuchung des männlichen Begattungsorganes die Gattungszugehörigkeit festzulegen, ist das sowohl bei Plateros wie bei Ditoneces nicht möglich, da in beiden Gattungen der Penis von grosser Vielgestaltigkeit ist." (i.e. While in many lycid genera it is possible to assign generic membership by comparison of male copulatory organs, this is possible neither in Plateros nor in Ditoneces, as the aedeagus is strongly polymorphic in both the genera). In spite of this fact Kleine preserved the genus Ditoneces. Unfortunately, the length of lamellae varies considerably, and closely related species often have both filiform and serrate to flabellate male antennae (e.g. Plateros cordatus group, Bocáková, 1997a). If all Plateros-like species with flabellate antennae were associated in Ditoneces (Kleine, 1933) then the genus would be polyphyletic. If only the type species Ditoneces punctipennis Waterhouse, 1878 was included in Ditoneces, then the genus Plateros would become paraphyletic having no apomorphic character. Therefore, Ditoneces Waterhouse is synonymized.

Cautirodes Pic, 1921 was proposed as a subgenus of Ditoneces for the single species Ditoneces (Cautirodes) malaccanus Pic, 1921, which has slender male antennae with long lamellae. The length of lamellae is within the range of variation of other species formerly placed in Ditoneces, and no additional distinguishing characters have been observed. Owing to this and together with reasons for the synonymization of Ditoneces given above, Cautirodes Pic, 1921 is synonymized.

Libnetomorphus Pic, 1921 was proposed as a genus close to Planeteros Gorham for 5 Plateros-like species, based on more or less elongate antennomere 3 . Because antennomere 3 of the type-species Libnetomorphus cephalotes Pic, 1921 is $1 / 5$ shorter than 4 , it is in the range of length of antennomere 3 of Plateros. As no other distinguishing characters have been recognized, Libnetomorphus is synonymized.

Microplateros Pic, 1921 was proposed as a genus close to Planeteros Gorham for 7 Plateros-like species with antennomere 3 more or less subtrianguloid. The typespecies Microplateros diversithorax Pic, 1921 as well as other included species have serrate male antennae, and therefore the shape of antennomere 3 is trianguloid. Unfortunately, the shape of antennomere 3 considerably varies in Plateros, and closely related species often possess antennomere 3 of different shape (Bocáková, 1997a, b). If all Plateros-like species with trianguloid antennomere 3 were associated in Microplateros then the genus would be polyphyletic. If only species closely related to the type species Microplateros diversithorax Pic, 1921 were included, then the genus Plateros would become paraphyletic having no apomorphic character, and therefore Microplateros is synonymized.

Melampyrus Waterhouse, 1879 was proposed for two species, both known only from females. Waterhouse (1879) stated that they differ from Plateros chiefly in being more pubescent and in having the antennae broader (serrate), and from Ditoneces in having alternate costae 


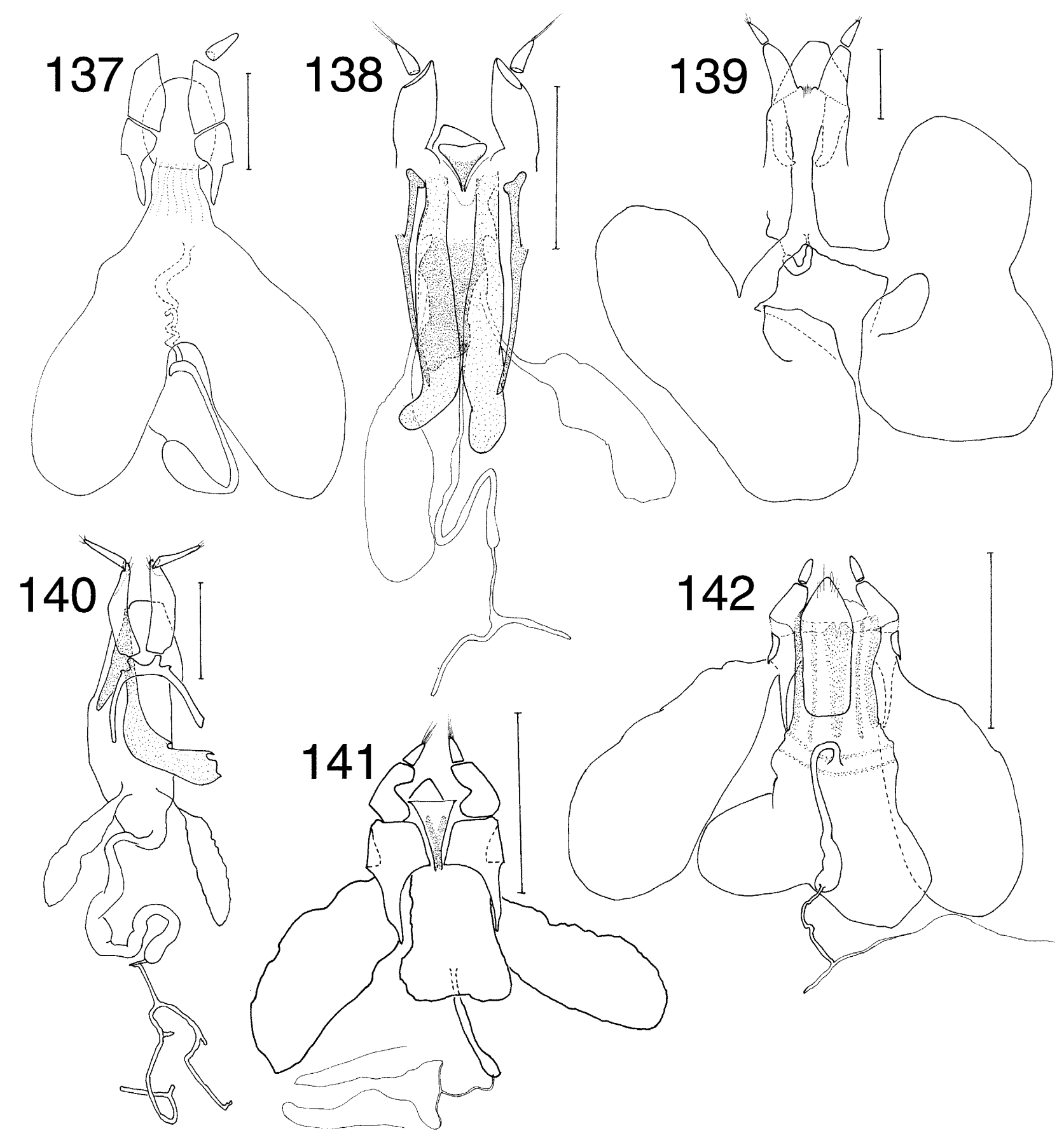

Figs 137-142. Female genitalia. 137 - Plateros fortecostatus (Pic); 138 - Dihammatus sp.; 139 - Plateros atroviolaceus; 140 Melaneros acuticollis; 141 - Libnetis pumilio; 142-Libnetis piceovittatus. Scale $=0.5 \mathrm{~mm}$.

(i.e. primary costae) of the elytra more elevated. All the characters vary considerably in many Plateros species mostly classified with Ditoneces by previous authors. Females of these species have also serrate antennae and the extent of pubescence can hardly be explicitly defined. More elevated primary elytral costae can also be found in some southeast Asiatic Plateros species as well as in South American Costatoplateros. Closely related species often have both slightly elevated and non-elevated elytral costae. If Melampyrus associated all Plateros-like species with slightly elevated alternate elytral costae then the taxon would be polyphyletic. If only species closely related to the type species Melampyrus alternans Waterhouse, 1878 were included then the genus Plateros would become paraphyletic having no apomorphic character. Therefore, Melampyrus Waterhouse, 1879 is synonymized.

Planeteros Gorham, 1883 was proposed for a single African species. Gorham (1883) stated that it was closely allied to the genus Plateros, and that "the key to the separation of these difficult genera of small Lycidae will be found in the proportion of antennal joints". Gorham had 
only a few specimens at his disposal, and therefore it was easy for him to separate these genera. Examination of much more material indicates that this is an artifact and antennal length of Planeteros is within the range of variation in Plateros. Although Kasantsev (1997b) downgraded Planeteros to subgeneric rank, it is here synonymized.

Tolianus Pic, 1921 was proposed for a single species as close to Melampyrus. It is based on a single female having 9 almost equal elytral costae and serrate antennae (antennae of the holotype are partly damaged and only antennomeres 1-4 are present). This specimen corresponds with females of those males having flabellate antennae that were hitherto placed in Ditoneces. Therefore similarly as Ditoneces, also Tolianus Pic, 1921 is synonymized.

As a result of the synonymization of these taxa, many secondary homonyms are created. However, assigning replacement names without revision would only add to a proliferation of names for taxa of unknown validity.

\section{Plateros brasiliensis (Lucas, 1857)}

(Figs 16, 38, 88, 126a-d)

Eros brasiliensis Lucas, 1857: 81

Diagnosis. Male genitalia of Plateros brasiliensis differ from those of known Plateros species in having two pairs of dorsal sutures in distal portion of aedeagus (Figs $126 \mathrm{~b}-\mathrm{d})$.

Redescription. $\delta$, Body dark brown to black, only pronotum (except median longitudinal spot), basal $\% / 10$ of elytra, trochanters, and bases of femora yellow. Head partly hidden by pronotum, eyes large, 1.3 times longer than interocular distance. Mandibles short, arcuate. Maxillary palpi 4-segmented, labial palpi 3-segmented. Both palpi with terminal palpomeres securiform. Antennae strongly serrate (Fig. 16). Antennomere 1 stout, pear-shaped, 2 very small, 4 is 1.3 times longer than 3 . Pronotum wider than long (Fig. 38), anterior margin semicircularly produced forwards, lateral margins divergent posteriorly, posterior angles projected obliquely backwards. Scutellum black, slightly widened anteriorly. Elytra 3.4 times longer than wide. Each elytron with 9 weak costae more or less of the same strength. Reticulate cells oval, irregular, legs compressed. Male genitalia composed of phallobase and phallus, paramerae absent. Phallus dorsodistally curved, ventroapical opening elongate (Figs 126a-d). Distal portion of phallus provided with two pairs of dorsal sutures. Body length: $8.0 \mathrm{~mm}$, humeral width: 1.9 $\mathrm{mm}$.

Type material. Neotype of Plateros brasiliensis (Lucas), hereby designated, $\overrightarrow{0}$, "Bras., Sao Paolo, Mráz lgt.“ (NMPC).

Distribution. Brazil.

Comments on neotype designation. The neotype is designated with the express purpose of clarifying the taxonomic status of $P$. brasiliensis, the type species of Plateros. The original description did not include either description of male genitalia or their drawings which are essential for any decision on species identity in Plateros.
Lucas' collection is deposited in the Natural History Museum in Paris. My search for the holotype was not successful there, and therefore the type specimen is considered to be lost (Dr. Ménier personal communication).

The neotype is the property of the National Museum in Prague and is consistent in all characters with the original description. Its redescription is given above. The neotype comes from Brazil, which is the original type locality of Plateros brasiliensis.

\section{Genus Cavoplateros Pic, 1913}

Cavoplateros Pic, 1913: 1.

Type species. Cavoplateros spinipes Pic, 1913 (by monotypy). Pseudeuplectus Pic, 1922b: 32, syn. n.

Type species. Cavoplateros (Pseudeuplectus) dentatus Pic, 1922 (by monotypy).

Diagnosis. Head with small eyes, interocular distance at least weakly longer than eye span, antennae usually widened apically, reaching over elytral midlength, antennomere 3 short, 1.3-1.6 times shorter than 4. Pronotum widest at base, posterior angles large, trianguloid, sides strongly emarginate laterally. Scutellum almost square, mesosternum trianguloid. Elytra elongate, parallel-sided, each elytron with 9 weak costae, reticulate cells irregular. Hind femora with long projections (Fig. 69, 70) heading to inner notch of tibiae, trochanters long. Sternum 8 weakly and widely emarginate at apex. Male genitalia without paramerae, phallus provided with a ventrobasal projection and two dull ventral projections in median portion.

Distribution. Brazil, Panama.

Comments. Cavoplateros Pic, 1913 was proposed for Cavoplateros spinipes having antennae strongly apically widened, and hind femora with long projections. The subgenus Pseudeuplectus was described for a single species Cavoplateros (Pseudeuplectus) dentatus having hind femora also with long projections, but antennal apex not dilated that is a plesiomorphy shared with other Platerodinae. Therefore Pseudeuplectus Pic, 1922 is a paraphyletic taxon, and consequently is synonymized to Cavoplateros Pic, 1913.

\section{Cavoplateros spinipes Pic, 1913}

(Figs 20, 34, 77, 84, 103-104)

Cavoplateros spinipes Pic, 1913: 1.

Diagnosis. Body dark brown, head with small eyes, antennae strongly widened apically, legs stout, middle tibiae apically strongly curved, and hind femora with acute projection. Male genitalia with weak, ventromedial, obtuse projection.

Redescription. Body dark brown to black. Head with small eyes, interocular distance 1.5 times eye diameter. Antennae widened apically, reaching weakly over elytral midlength. Antennomere 1 stout, 2 very small, 3 twice longer and wider, 4 much longer than 3 , terminal antennomeres strongly widened apically (Fig. 20). Pronotum slightly transverse, strongly ventromedially depressed, widest at base, anterior margin weakly produced forwards, sides elevated, strongly emarginate medially. 
Scutellum with shallow arcuate apical notch. Elytra elongate, subparallel-sided, about 3.8 times as long as humeral width, weakly wider than base of pronotum. Each elytron with 9 weak costae, reticulate cells poorly defined and irregular. Mesosternum trianguloid, wing venation with $\mathrm{AP}_{3+4}$ absent. Abdominal sternum 8 with weak distal emargination, sternum 9 long (Fig. 84). Legs stout, compressed, middle tibiae apically strongly curved, tibial spurs small, slender and acute, trochanters elongate, hind femora with acute projection. Male genitalia with two weak ventromedial obtuse promontories and a dorsolateral spinose projection in median portion of phallus (apex of phallus of holotype broken and absent). Body length $6 \mathrm{~mm}$, humeral width $1.3 \mathrm{~mm}$.

Type material. Holotype of Cavoplateros spinipes Pic,,$\vec{\circ}$, "Brazil" (MNHN).

Distribution. Brazil.

Cavoplateros dentatus Pic, 1922

(Figs 19, 36, 89, 101-102)

Cavoplateros dentatus Pic, 1922b: 32.

Diagnosis. Body dark brown, lateral belts of pronotum yellow. Interocular distance almost as long as eye diameter, antennae filiform, pronotum dorsomedially convex. Abdominal sternum 9 short and wide, provided with a hole, tergum 9 partly fused to 10 . Male genitalia with two strong ventromedial projections.

Redescription. Body dark brown, lateral belts of pronotum yellow. Head with larger eyes, interocular distance 1.05 times as long as eye diameter, antennae filiform, long, reaching apical third of elytra. Antennomere 1 stout, 2 very small, 3 twice longer than 2 , antennomere 4 is 1.3 times longer than 3. Labrum transverse, mandibles arcuate, maxillary palpi slender, second palpomere long, terminal palpomere elongate, its sides subparallel, apex oblique. Pronotum transverse, 1.3 times as wide as its length, widest at base, anterior margin weakly produced forwards, lateral margins elevated, strongly emarginate medially, posterior angles trianguloid, acute. Scutellum almost square. Elytra elongate, subparallel-sided, about 3.5 times as long as humeral width, weakly wider than base of pronotum. Each elytron with 9 weak costae, reticulate cells irregular. Mesosternum trianguloid, wing venation with transverse vein $\mathrm{CuA}_{1}$ attached to $\mathrm{MP}_{3+4}$ in the point of its bifurcation, transverse vein $\mathrm{CuA}_{2}$ and short vein $\mathrm{AP}_{3+4}$ absent. Abdominal sternum 8 weakly widely emarginate apically, sternum 9 short and wide, provided with a hole, tergum 9 partly fused to 10 (Fig. 89). Legs slender, compressed, middle tibiae almost straight, tibial spurs small, trochanters elongate, hind femora with long obtuse projection. Male genitalia with two strong ventromedial projections, distal portion of phallus semicircularly curved. Body length $5.25-5.45 \mathrm{~mm}$, humeral width $1.1-1.2 \mathrm{~mm}$.

Type material. Syntypes of Cavoplateros dentatus Pic, 2 , Panama: "V. de Chiriqui, 4000-6000 ft, Champion" (MNHN). Distribution. Panama.

Taxa incertae sedis within Platerodini

Plateros (Mimolycinella) basicornis Pic, 1925
Mimolycinella Pic, 1925: 18 - subgenus of Plateros.

Type species. Plateros (Mimolycinella) basicornis Pic, 1925 (by monotypy).

\section{Sculptocalleros discithorax Pic, 1949}

Sculptocalleros Pic, 1949: 5.

Type species. Sculptocalleros discithorax Pic, 1949 (by monotypy).

Comments. Type species of Mimolycinella and Sculptocalleros should be deposited in M. Pic's collection (MNHN). Unfortunately, searching for them within MNHN has not been successful, although it is possible they can be found there in the future. As the original descriptions are entirely insufficient, these taxa are kept within Platerodini incertae sedis.

\section{Genera incertae sedis within subfamily Platerodinae} Genus Microlycus Pic, 1922

Microlycus Pic, 1922a: 22.

Type species. Microlycus minutus Pic, 1922 (by monotypy).

Diagnosis. Head with small eyes, interocular distance twice eye diameter. Antennae filiform, reaching elytral midlength. Antennomere 1 stout, 2 very small, 3 almost twice longer than 2. Antennomere 4 twice longer than 3 . Labrum transverse, mandibles reduced but stout, distally arcuate, maxillary palpi long with terminal palpomere securiform, labial palpi short. Pronotum transverse, widest at basal margin, anterior angles rounded. Pronotum flat, disc without carinae, median longitudinal line channelled at base. Scutellum slightly apically emarginate. Elytra elongate, semicircularly widened. Each elytron with 9 costae, reticulate cells conspicuous, primary costae 2 and 4 strongly elevated. Wing venation with $\mathrm{AP}_{3+4}$ absent. Female terminal sternum somewhat elongate, spiculum gastrale present, shorter than half of sternum. Legs compressed, tibiae straight, their spurs small, acute. Female genitalia with long, basally fused valvifers, coxites partly coalescent. Body length 5.4-5.9 $\mathrm{mm}$, humeral width: $1.7-2.4 \mathrm{~mm}$. Male unknown.

Distribution. Mexico.

Comments. Performance of the cladistic analysis of Platerodinae did not help too much to elucidate the relationships of Microlycus, although certain relatedness to Calolycus was indicated. In the resultant cladogram (Fig. 1b) both the genera had basal placement after Lyponia. One of the two most parsimonious trees obtained by computer analysis (Fig. 4) included also the branch Microlycus - Calolycus, and the same tree topology was obtained using successive weighting. Regardless, the group Microlycus - Calolycus is not adopted in the classification because male of Microlycus is not known, and the clade Microlycus - Calolycus was based on absence of paramerae. Moreover, these genera differ substantially in the morphology of female genitalia, the clade Microlycus - Calolycus has split in the strict consensus tree, and has low bootstrap and jackboot values.

\section{Microlycus minutus Pic, 1922}

(Figs 22, 35, 92, 128)

Microlycus minutus Pic, 1922a: 22. 
Redescription. + . Body dark brown, only pronotum (except basal median spot) yellow. Head small, partly concealed by pronotum, eyes small, interocular distance twice as long as eye span. Antennae filiform, reaching elytral midlength. Antennomere 1 stout, 2 very small, 3 almost twice longer than 2. Antennomere 4 is the longest of all, twice longer than 3 , but 1.5 times longer than 5 . Labrum transverse, mandibles short but stout, distally arcuate, their apices do not touch each other, maxillary palpi long with terminal palpomere weakly narrowed apically, labial palpi short. Pronotum oblong, strongly transverse, widest at basal margin, anterior angles rounded, posterior ones projected obliquely backwards. Pronotum flat, without areolae, sides slightly elevated. Scutellum apically emarginate. Elytra elongate, semicircularly widened in posterior half, about 2.8 times as long as humeral width. Each elytron with 9 costae, reticulate cells well expressed, primary costae 2 and 4 strongly elevated. Mesosternum trapezoidal, wing venation with $\mathrm{AP}_{3+4}$ absent. Spiculum gastrale short, shorter than half of female terminal sternum. Legs rather slender, compressed, tibiae straight, their spurs small, negligible, trochanters short. Female genitalia with long basally coalescent valvifers, coxites basally fused, styli half shorter than coxites. Body length $5.4 \mathrm{~mm}$, humeral width: $1.7 \mathrm{~mm}$. Male unknown.

Type material. Lectotype $q$ (hereby designated), "Jalapa, Mexico, F. Schneider" (MNHN).

Distribution. Mexico.

Comment. The lectotype designation is made with the purpose of clarifying the application of the name Microlycus minutus Pic to the species figured in figs 22, 35, 92, 128 , and to distinguish it from the other syntype that represents the following species.

\section{Microlycus mexicanus sp. $\boldsymbol{n}$.}

(Figs 21, 35a, 68, 93, 132)

Diagnosis. It differs from $M$. minutus in having pronotum anteriorly produced, antennomere 4 as long as 5, and valvifers separate.

Description. + . Body dark brown, only pronotum (except basal median spot) yellow. Head small, almost concealed by pronotum, eyes small, interocular distance twice as long as eye span. Antennae filiform and stout, reaching elytral midlength. Antennomere 1 stout, 2 very small, 3 almost as long 2 but 1.5 times wider than 2 . Antennomere 4 twice as long as 3 . Labrum transverse, mandibles stout, strongly arcuate in distal portion, their apices obliquely crossed at rest. Maxillary and labial palpi with terminal palpomeres securiform, widened apically. Pronotum subpentagonal, weakly transverse, widest at base, anterior margin strongly produced forwards, anterior angles rounded, lateral margins convex. Pronotum flat, disc without carinae, median longitudinal line channelled at base, sides slightly elevated. Scutellum oblong, longer than wide, impressed at apex. Elytra elongate, about 2.9 times as long as humeral width, widest medially, sides behind humerus arcuate. Each elytron with 9 costae, reticulate cells conspicuous, primary costae 2 and 4 strongly elevated. Mesosternum rather trapezoidal, proximal margin slightly emarginate, posterior margin rounded. Wing venation with $\mathrm{AP}_{3+4}$ absent. Female terminal sternum somewhat elongate, spiculum gastrale present, shorter than half of the sternum. Legs with stout femora, tibiae straight and compressed, their spurs small, acute, front and median trochanters elongate, hind rather stouter. Female genitalia with long basally approached valvifers, coxites basally fused, styli small.

Body length. $5.9 \mathrm{~mm}$, humeral width: $2.4 \mathrm{~mm}$. Male unknown.

Etymology. Named according to the type locality.

Type material. Holotype + , "Jalapa, Mexico, F. Schneider" (MNHN).

Distribution. Mexico.

\section{Genus Calolycus Gorham, 1881}

(Figs 24, 37, 65, 71, 82, 90, 119-120, 130)

Calolycus Gorham, 1881: 27.

Type species. Calolycus calanticatus Gorham, 1881 (by monotypy).

Diagnosis. Antennomere 3 short, pronotum without carinae, posterior angles of pronotum projected obliquely backwards. Elytra with primary costae 2 and 4 strongly elevated, aedeagus without paramerae, dorsoventrally curved, provided with long phallobase, valvifers short, stick-formed.

Redescription. Head small, almost concealed by pronotum, eyes small, interocular distance 1.1 times as long as eye diameter. Antennae filiform, reaching elytral midlength. Antennomere 1 stout, 2 very small, 3 almost twice longer than 2. Antennomere 4 twice longer than 3 . Pronotum transverse, widest at basal margin, anterior angles rounded, posterior angles projected obliquely backwards. Pronotum flat, disc without carinae, median longitudinal line channelled at base. Scutellum emarginate apically. Elytra elongate, semicircularly widened. Each elytron with 9 costae, reticulate cells conspicuous, primary costae 2 and 4 strongly elevated. Wing venation with transverse vein $\mathrm{CuA}_{1}$ attached to $\mathrm{MP}_{4}$ in its proximal sixth, brace $\mathrm{CuA}_{2}$ hardly visible, $\mathrm{AP}_{3+4}$ absent. Legs stout, compressed, tibiae straight, and their spurs small, acute. Male terminal sternum widely rounded proximally, aedeagus without paramerae, dorsoventrally curved, provided with long phallobase. Female terminal sternum transverse, spiculum gastrale only indicated as a protrusion. Female genitalia with short valvifers widened basally, which are fused to coxites. Body length $6.25 \mathrm{~mm}$, humeral width: $2.1 \mathrm{~mm}$.

Type material. Syntype of Calolycus calanticatus, $\overrightarrow{0}$, "Mexico, Cordova, Sallé coll." (BMNH), syntype of Calolycus calanticatus, + , the same data (BMNH)

Other material. Mexico: Sallé lgt., without other data, 1 q(MNHN), Jalapa, 1 ( (ZMHB); Costa Rica: Turialba, A. Heyne lgt., 1 o (ZMHB)

Distribution. Mexico, Costa Rica.

Comments. The reasons for leaving Calolycus incertae sedis within Platerodinae are the same as for Microlycus (see comments on Microlycus). 


\section{Taxa excluded from Platerodinae}

Leptolycinae Leng \& Mutchler, 1922

Leptolycini Leng \& Mutchler, 1922: 430.

\section{Genus Fernandum Pic, 1924}

(Figs 64, 121-122)

Fernandum Pic, 1924: 161.

Type species. Fernandum minutum Pic, 1924 (by monotypy).

Diagnosis. Head with strongly prominent antennal tubercles, antennae flabellate, mandibles absent, terminal palpomeres of both palpi apically pointed, pronotum trapezoidal, without carinae, each elytron with 4 costae, costa 1 shortened, absent in distal elytral half, secondary costae absent, reticulate cells somewhat oblong.

Redescription. Body entirely yellow. Head with small eyes, interocular distance 1.2 times as long as eye span. Antennal tubercles large, strongly anteriorly prominent. Antennae flabellate, reaching elytral midlength. Antennomere 3 widely trianguloid, $4-10$ with lamellae as long as respective antennomeres. Mandibles absent, terminal palpomeres of maxillary and labial palpi strongly apically pointed. Pronotum trapezoidal, transverse, widest at basal margin, anterior margin straight, sides elevated, concave, posterior angles acute. Pronotum without carinae, also median longitudinal line anteriorly absent, present in posterior half. Scutellum with a shallow arcuate apical notch. Elytra elongate, subparallel-sided, about 3 times as long as humeral width and $1 / 6$ wider than pronotum. Each elytron with 4 costae, costa 1 evolved in anterior half, therefore elytra medially narrowed in posterior sutural region and sutural margins divergent in posterior half. Secondary costae absent, some remnants present at base. Reticulate cells of irregular shape, more or less oblong. Mesosternum transverse, with widely rounded apex. Wing venation with $\mathrm{CuA}_{1}$ attached to $\mathrm{MP}_{3+4}$ before its bifurcation, $\mathrm{CuA}_{3+4}$ stout and semicircularly attached to $\mathrm{CuA}_{2}, \mathrm{AP}_{3+4}$ short. Abdominal sternum 8 with a trianguloid distal emargination. Legs rather stout and short, compressed, tibiae widened distally, trochanters elongate, hind trochanters somewhat trianguloid. Male genitalia with paramerae strongly modified, apically forming two lateral dents, phallus strongly reduced, its hardly visible remnant present in median portion. Female unknown. Body length. $3.45 \mathrm{~mm}$, humeral width: $1.05 \mathrm{~mm}$.

Type material. Holotype of Fernandum minutum, o’, "Is. Fernando Poo, Paphia de S. Carlos, I. 1902, 200 m, L. Fea" (MCSN).

Comments. Kleine (1933) classified the genus Fernandum Pic within the tribe Platerodini. On the basis of sharing some apomorphies of the genus Dexoris Waterhouse, 1878 (shape of head, reduced mouth-parts) it is transferred to the subfamily Leptolycinae (see Bocák \& Bocáková, 1990).

\section{Genus Subdihammatus Kleine, 1926}

(Figs 117, 118)

Subdihammatus Kleine, 1926: 68.

Type species. Subdihammatus curvus Kleine, 1926 (by monotypy).
Diagnosis. Head partly concealed by pronotum, antennal tubercles conspicuous, eyes small, interocular distance almost twice as long as the span of the lens. Antennae filiform, reaching elytral midlength. Antennomere 1 stout, basally constricted, antennomeres 2 and 3 very small, 3 weakly longer than 2 . Antennomere 4 is the longest of all, slightly longer than 5 . Terminal maxillary palpomere apically pointed. Pronotum trapezoidal, anterior margin weakly produced forwards, anterior angles conspicuous. Scutellum small, deeply emarginate in apical third. Each elytron with 4 primary costae, secondary costae sometimes irregular to obliterate. Aedeagus with long, dorsally fused paramerae, phallus dorsally curved in distal portion. Female unknown.

Type material. Holotype, ठ̊, "Luzon, Mt. Makiling, Baker" (ZMPA).

Distribution. Philippines.

Comments. On the basis of the shape of male genitalia (Figs 117, 118) and reduced mouthparts the genus is transferred to the subfamily Leptolycinae (see Bocák \& Bocáková, 1990). Within this subfamily, Subdihammatus seems to be related to the recently described Skrivania Bocák et Bocáková, 1999 from Malaysia. Unfortunately, Kleine destroyed the basal portion of holotype aedeagus when he dissected it, and therefore the comparison of phallobases is impossible.

\section{Genera incertae sedis in Lycidae \\ Genus Melaneros Fairmaire, 1877}

(Figs 83, 115-116, 140)

Melaneros Fairmaire, 1877: 173.

Type species. Melaneros acuticollis Fairmaire, 1877 (subsequent designation by Bourgeois, 1891).

Samoaneros Blair, 1928: 101, syn. n.

Type species. Melaneros acuticollis Fairmaire, 1877 (original designation by Blair, lectotype in MNHN).

Comments. Blair (1928) overlooked fixation of the type species Melaneros acuticollis for the genus Melaneros made by Bourgeois (1891), and proposed a new genus Samoaneros for the same species. Therefore, Samoaneros Blair, 1928 is considered to be a younger objective synonym of Melaneros Fairmaire, 1877.

Holotype of Melaneros acuticollis Fairmaire was deposited in the Zoological Museum in Hamburg, and was destroyed during the World War II. I have examined specimens identified by Blair deposited in BMNH that seem to correspond to Blair's (1928) redescription and drawings. Melaneros possesses many autapomorphies, but does not show the synapomorphies of Platerodinae. Examination of its female genitalia (Fig. 140) suggests some relatedness either to Metriorrhynchinae Kleine, 1926 or to tribe Calopterini of the subfamily Lycinae (see Bocák \& Bocáková, 1990). Because its relationships are not sufficiently supported I leave the genus incertae sedis within the family Lycidae.

\section{Genus Platerodrilus Pic, 1921}

Platerodrilus Pic, 1921b: 13.

Type species. not designated yet. 
Macrolibnetis Pic, 1938: 281, syn. n.

Type species. Macrolibnetis depressus Pic, 1938 (by monotypy).

Type material. Holotype of Macrolibnetis depressus, (BMNH), "Pahang, Cameron Highlands, 4500-5000 ft, June17, 1935, leg. H. M. Pendlebury".

Distribution. Malaysia.

Comments. Although Duliticola Mjöberg, 1925 has always been classified with Lycidae, its close relative the genus Platerodrilus was long considered to be a member of Drilidae. Crowson (1972) transferred Platerodrilus to Lycidae. Similarly Bocák \& Bocáková (1990) regarded Platerodrilus to belong to Lycidae although they kept it incertae sedis within the family. The relationships of Platerodrilus and Duliticola need further study (Wong, 1996) which should result in the final decision whether to treat these close taxa as separate genera. Because the holotype of Macrolibnetis depressus bears all characters of the genus Platerodrilus as shape of head, long and stout mandibles, shape of pronotum as well as elytral structure, the genus Macrolibnetis Pic, 1938 is considered to be a junior synonym of Platerodrilus Pic, 1921.

ACKNOWLEDGEMENTS. I would like to thank many entomologists and institutions which provided material for this study, particularly to J. Beard (The Natural History Museum, London, BMNH), R. Poggi (Museo Civico Di Storia Naturale, Genova, Italy), R. Brett (California Academy of Sciences), T. Huflejt (Zoological Institute, Warszawa), F. Hieke (Zoologisches Museum der Humboldt-Universität, Berlin), and especially to J. Ménier (Muséum d'Histoire naturelle, Paris). Thanks also to my husband, L. Bocák for his help with the Random Cladistics and Tree Gardener computer programs and many invaluable comments. I especially thank anonymous reviewers for their comments and criticisms, and particularly for the recommendation to incorporate all the synonymized taxa into the phylogenetic analysis. This study has been supported by a grant no 97P01OMG79 from the Ministry of Culture of the Czech Republic.

\section{REFERENCES}

BLAIR K.G. 1928: Insects of Samoa. Heteromera, Bostrychoidea, Malacodermata and Buprestidae., part IV. (2): 67-109.

BOCÁK L. 1998: A generic revision and phylogenetic analysis of the subtribe Trichalinina (Coleoptera: Lycidae: Metriorrhynchini). Acta Soc. Zool. Bohem. 62: 167-200.

BocÁK L. 1999: A revision and the phylogenetic analysis of the genus Lyponia C.O. Waterhouse (Coleoptera, Lycidae). Entomologica Basiliensia. 21: 59-103.

BocÁk L. \& BocÁková M. 1990a: Revision of the supergeneric classification of the family Lycidae (Coleoptera). Polskie Pismo Entomol. 59: 623-676.

BoCÁK L. \& BOCÁKOVÁ M. 1990b: Revision of the genus Plateros Bourgeois (Coleoptera, Lycidae) from Sri Lanka with several notes on Ditoneces species. Annot. Zool. Bot. 200:1-29.

BocÁK L. \& BocÁková M. 1992: Notes on some genera of the family Lycidae (Insecta, Coleoptera). Entomologica Basiliensia 15: 255-260.

Bocák L. \& BocÁKová M. 1999: New Lycidae from Peninsular Malaysia (Coleoptera). Entomologica Basiliensia 21: 255-260.
Bocákové M. 1997a: Revision and phylogenetic analysis of the genus Melaneros Fairmaire, 1877 (Coleoptera, Lycidae) from New Guinea. Entomologica Basiliensia 20: 165-222.

BocÁKOvÁ M. 1997b: Revision of the genus Melaneros from China with a note on Ditoneces (Coleoptera: Lycidae). Acta Soc. Zool. Bohem. 61: 175-190.

Bourgeors J. 1879: Lycides recueillis au Brésil par C. Van Volxem. Ann. Soc. Entomol. Belg. 22: 15-19.

Bourgeols J. 1891: Distribution géographique des Malacodermes. Ann. Soc. Entomol. Fr. 60: 337- 364.

CARPENTER J.M. 1996: Uninformative bootstrapping. Cladistics 12: 177-181.

CRowson R.A. 1972: A review of the classification of Cantharoidea (Coleoptera), with the definition of two new families, Cneoglossidae and Omethidae. Rev. Univ. Madrid 21: 35-77.

Dillon N., Austin A.D. \& Bartowsky E. 1996: Comparison of preservation techniques for DNA extraction from hymenopterous insects. Insect Mol. Biol. 5: 21-24.

FaIrmarre L. 1877: Diagnoses de Coléoptères australiens et mélanésiens. Petites Nouv. Entomol. 2:173-174.

FaIrmarRe L. 1899: Descriptions de Coléoptères nouveaux recueillis en Chine par M de Latouche. Ann. Soc. Entomol. Fr. 68: 616-642.

FARRIS J.S. 1988: Hennig86, version 1.5. Program and documentation. Port Jefferson Station, New York.

Gorham H. S. 1881: Malacodermata. Fam. Lycidae. Biol. Centr. Am. Col. 3: 1-29.

GoRHAM H.S. 1883: Descriptions of Malacodermata in the Civic Museum of Natural History at Genoa. Ann. Mus. Civ. Stor. Nat. Genova 18: 591-606.

GorHam H.S. 1884: Malacodermata. Suplement. Fam. Lycidae. Biol. Centr. Am. Col. 3: 225-272.

Green J.W. 1951: The Lycidae of the United States and Canada III. The tribe Platerodini (in part) (Coleoptera). Trans. Am. Entomol. Soc. 77: 1-20.

GreEN J.W. 1953: The Lycidae of the United States and Canada V. Plateros (Coleoptera). Trans. Am. Entomol. Soc. 78: 149-181.

Kasantsev S. 1997a: New and little known Lycidae (Coleoptera) from southeast Asia. Raffl. Bull. Zool. 45: 173-187.

KASAnTSev S. 1997b: Sur le sous genre Planeteros (Coleoptera, Lycidae). Rev. Fr. Entomol. (N.S.) 19: 1-17.

KLEINE R. 1926: Die Lyciden der Philippinen-Inseln. Philipp. J. Sci. 1926: 33-114.

KLEINE R. 1927: Libnetomimus eine neue Lycidengattung von den Philippinen-Inseln. Soc. Entomol. 42: 1-2.

KleINe R. 1928: Neue Indische Lycidae nebst faunistischen Bemerkungen. Ind. Forest Rec. 13: 221-268.

Kleine R. 1933: Lycidae Pars 128. In Junk W. \& Schenkling S. (eds): Coleopterorum Catalogus auspiciis et auxilio. W. Junk, Berlin, $145 \mathrm{pp}$.

Kluge A.G. \& Farris J.S. 1969: Quantitative phyletics and the evolution of annurans. Syst. Zool. 18: 1-32.

Leng C.W. \& Mutchler A.J. 1922: The Lycidae, Lampyridae and Cantharidae (Telephoridae) of the West Indies. Bull. Am. Mus. 46: 413-431.

LuCAS M.H. 1857: Animaux nouveaux ou rares recueillis pendant l'expédition dans les parties centrales l'Amérique du sud, Part Entomologie, Lycides. Bertrand, Paris, pp. 81-85.

LiPsComB D. 1994: Cladistic analysis using Hennig86. Manual. George Washington University, Washington. $122 \mathrm{pp}$.

MiLLER R.S. 1997: Immature Stages of Plateros floralis (Melsheimer) and discussion of Phylogenetic Relationships (Coleoptera: Lycidae). Coleopt. Bull. 51: 1-12. 
MJÖBERG E. 1925: Mystery of "trilobite larva" definitely solved. Psyche 32: 119-154.

NAKANE T. 1969: Fauna Japonica, Lycidae (Insecta, Coleoptera). Academic Press of Japan, Tokyo, 224 pp.

NIXON 1995: Clados version 1.9. MS-DOS program. Cornell University, Ithaca.

PIC M. 1913: Nouveaux genres et nouvelles espèces. Mélanges Exot.- Entomol. 6:1-20.

PIC M. 1921a: Contribution à l'étude des Lycides. L'Echange 404-406: 1-11, hors texte.

PIC M. 1921b: Nouveautés diverses. Mélanges Exot.- Entomol. 33: $1-32$.

PIC M. 1922a: Contribution à l'étude des Lycides. L'Echange 407-410: 12-27, hors texte.

PIC M. 1922b: Nouveautés diverses. Mélanges Exot.- Entomol. 36: $1-32$.

PIC M. 1923: Contribution à l'étude des Lycides. L'Echange 411-413: 28-40, hors texte.

PIC M. 1924: Lycides africains nouveaux. Ann. Mus. Civ. Stor. Nat. Genova. 51: 161

PIC M. 1925: Malacodermes exotiques. L'Echange 422: 16-19, hors texte.

PIC M. 1929: Coléoptères exotiques en partie nouveaux. L'Echange 435: 4 pp.

PIC M. 1933: Malacodermes exotiques. L'Echange 451 109-112, hors texte.

PIC M. 1938: Divers Coléoptères nouveaux de la presqui'ile Malaise (IV). J. Feder. Malay. Stat. Mus. 18: 279-286.
PIC M. 1949: Coléoptères du globe. L'Echange 516: 5-8.

Ramos T. C. 1997: Tree Gardener version 2.2. Museu de Zoologia, USP, Sao Paulo.

SiDDALL M. 1996: Random Cladistics, version 4.0.3, Ohio edition. MS DOS program. Virginia Institute of Marine Sciences, Gloucester Point.

Townson H., Harbach R.E. \& Callan T.A. 1999: DNA identification of museum specimens of the Anopheles gambiae complex: an evaluation of PCR as a tool for resolving the formal taxonomy of sibling species complexes. Syst. Entomol. 24: 95-100.

WATERHOUSE C.O. 1878: On the different forms occurring in the coleopterous family Lycidae, with description of new genera and species. Trans. Entomol. Soc. Lond. 1878: 95-118.

WATERHOUSE C.O. 1879: Illustrations of typical specimens of Coleoptera in the collection of the British Museum. Part I. Lycidae. British Museum, London, 93 pp.

WATRous L.E. \& WHEELER Q.D. 1981: The out-group comparison method of character analysis. Syst. Zool. 30: 1-11.

WoNG A.T. 1996: A new species of neotenous beetle, Duliticola hoiseni (Insecta: Coleoptera: Cantharoidea: Lycidae) from peninsular Malaysia and Singapore. Raffl. Bull. Zool. 44: 173-187.

ZARAGOZA C.S. 1999: Cantharoidea (Coleoptera) de Mexico. III. El genero Plateros Bourgeois (Lycidae: Erotinae: Platerodini). Acta Zool. Mex. 78: 1-71.

Received September 9, 1999; accepted July 3, 2000 